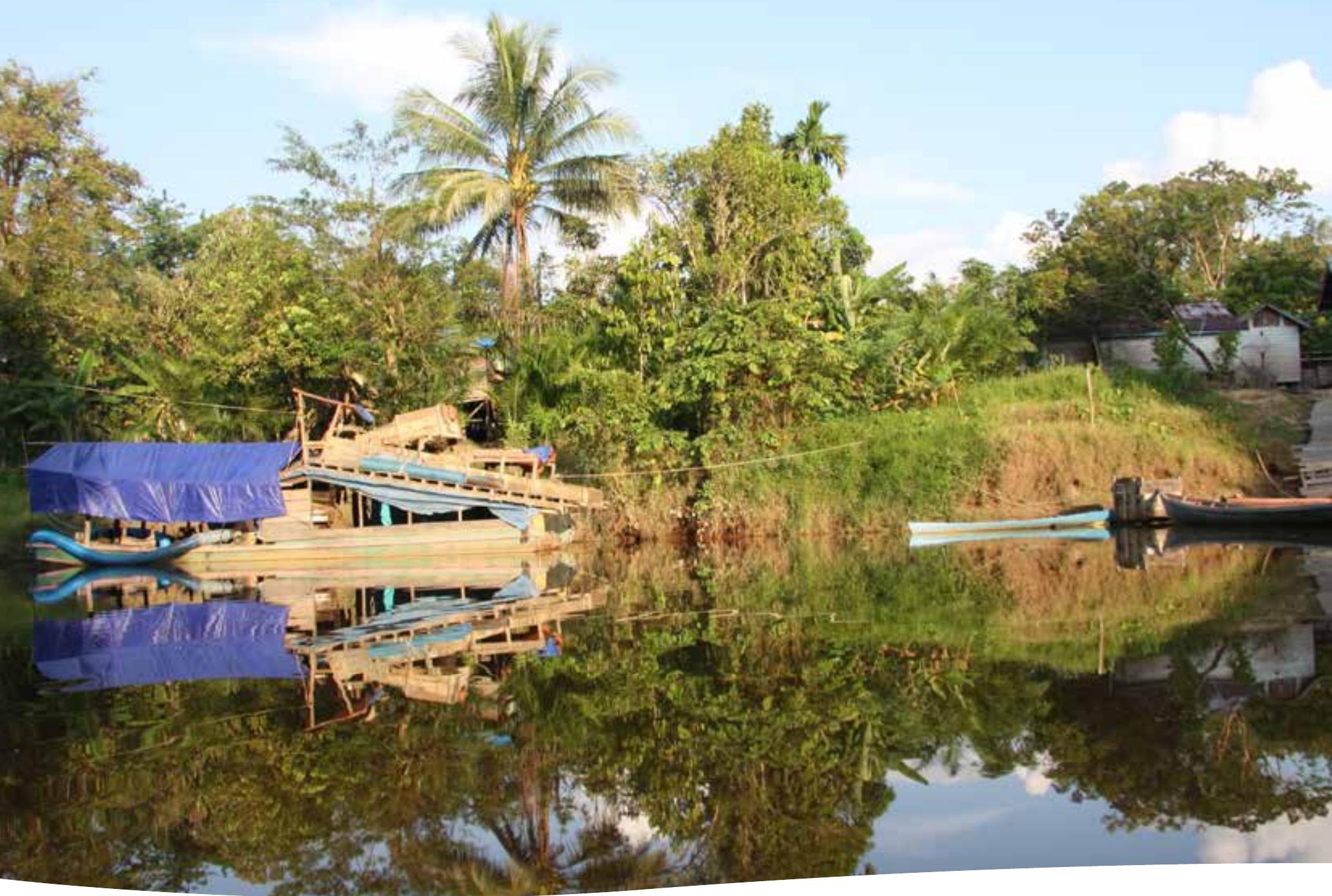

\title{
Traditional knowledge, perceptions and forest conditions in a Dayak Mentebah community, West Kalimantan, Indonesia
}





\section{Traditional knowledge, perceptions and forest conditions in a Dayak Mentebah community, West Kalimantan, Indonesia}

Edith Weihreter

Center for International Forestry Research (CIFOR) 
Working Paper 146

(c) 2014 Center for International Forestry Research

(c) (1) Content in this publication is licensed under a Creative Commons Attribution 4.0 International (CC BY 4.0), http://creativecommons.org/licenses/by/4.0/

Weihreter E. 2014. Traditional knowledge, perceptions and forest conditions in a Dayak Mentebah community, West Kalimantan, Indonesia. Working Paper 146. Bogor, Indonesia: CIFOR.

Photo by Edith Weihreter/CIFOR

Nanga Dua Village on Penungun River with canoes and a gold digging boat

CIFOR

Jl. CIFOR, Situ Gede

Bogor Barat 16115

Indonesia

$\mathrm{T}+62(251) 8622-622$

$\mathrm{F}+62(251) 8622-100$

E cifor@cgiar.org

\section{cifor.org}

We would like to thank all donors who supported this research through their contributions to the CGIAR Fund. For a list of Fund donors please see: https://www.cgiarfund.org/FundDonors

Any views expressed in this publication are those of the authors. They do not necessarily represent the views of CIFOR, the editors, the authors' institutions, the financial sponsors or the reviewers. 
You have your way. I have my way. As for the right way, the correct way, and the only way, it does not exist.

FRIEDRICH NIETZSCHE 


\section{Table of content}

List of abbreviations

Acknowledgments $\quad$ vii

1 Introduction 1

1.1 Forests in Kalimantan: A changing environment 1

1.2 Indigenous-community-based forest management systems in Kalimantan 2

1.3 Kapuas Hulu Regency 3

1.4 Aim of this study 3

2 Materials and methods $\quad 5$

2.1 The territory of Nanga Dua $\quad 5$

2.2 Methods 6

2.3 Free listing of trees and medicinal plants 9

3 Results 11

3.1 Activities, history and socioeconomic situation of Nanga Dua 11

3.2 Perception of the land use, landscape and species values 12

3.3 Traditional medicinal plants and their uses 16

$\begin{array}{ll}3.4 \text { Ecological analysis } & 17\end{array}$

3.5 Free lists of trees and medicinal plants $\quad 19$

4 Discussion $\quad 20$

4.1 Gender-related observations 20

$\begin{array}{ll}4.2 \text { Medicinal plant listing } & 20\end{array}$

$\begin{array}{ll}4.4 \text { The free listing method } & 20\end{array}$

4.5 Ecological analysis 21

4.6 The Kerangas $\quad 21$

4.7 The role of vulnerable forestry resources 21

5 Conclusion $\quad 22$

6 References 23

Appendices $\quad 27$

1 Two data sheet examples for the 60 free lists of species of medicinal plants and trees

2 Basketry

3 Important species for each use category

4 Data sheet for the pdm: Importance of each land unit for the use categories

5 Data sheet for the PDM: Source of income

6 Data sheet for the PDM: Past present future

7 The nine remedies other than plants

8 List of the 125 medicinal plants 


\section{List of figures and tables}

\section{Figures}

1 Deforestation in Borneo

2 Location of the Indonesian province of West Kalimantan, in green 4

3 Location of study site. In color: the Kapuas Hulu district.

Red dot: Nanga Dua Village, the study location 4

4 Vegetation map and localisation of the study site, established by CoLUPSIA using Landsat satellite imagery from 2009

6 Zoom on 2 out of 10 plots laid in a row in the lowland hill forest 8

7 Calendar of swidden agriculture and other activities 11

8 The eight land-use units established during the focus group discussion 13

9 The eight land-use categories established during the focus group discussion $\quad 13$

10 Map of the land types and land use constructed by the men group 14

11 Importance of each land unit with regard to different use categories 15

12 Importance of each land unit regarding medicinal plants (men and women) 16

13 Importance of land-use types with regard to income 16

14 Change of perception in time, past-present-future (men and women groups) 17

15 Proportions of the traditional medicines found in different landscape units 17

\section{Tables}

1 Plot site description 8

2 Calculations for the importance value index 10

3 The dbh classes and the total amount of trees per land unit 17

4 Diversity index D = $1-\lambda$ calculated through the Simpson index $\lambda \quad 18$

5 The 10 most salient trees and medicinal plants for women and men 18 


\section{List of abbreviations}

$\begin{array}{ll}\text { BAi } & \text { individual tree basal area } \\ \text { CIFOR } & \text { Center for International Forestry Research } \\ \text { CIRAD } & \text { Centre de coopération Internationale en Recherche Agronomique pour le Développement } \\ \text { CoLUPSIA } & \text { Collaborative Land Use Planning and Sustainable Institutional Arrangements } \\ \text { D } & \text { diversity index (measured by Simpson index } \lambda \text { ) } \\ \text { dbh } & \text { diameter at breast height } \\ \text { IDR } & \text { Indonesian rupiah } \\ \text { IUCN } & \text { International Union for Conservation of Nature } \\ \text { IVI } & \text { importance value index } \\ \text { NGO } & \text { non-governmental organization } \\ \text { PDM } & \text { pebbles distribution method } \\ \text { RBA } & \text { relative basal area for each species } \\ \text { RD } & \text { relative density for each species } \\ \text { Smith S } & \text { Smith's index of salience } \\ \text { sp. } & \text { species not identified (identified to genus level only) } \\ \lambda & \text { Simpson index } \lambda\end{array}$




\section{Acknowledgments}

First I would like to thank Yves Laumonier, who made this internship possible, for his help and support. His trust in me was crucial for the success of this work. Thanks also to our friend, Marion Comptour. I would like to thank my teachers at University Montpellier II for giving me a methodological basis, particularly Errol Vela who advised me during this internship. Popi Astriani supported me in administrative matters in a reliable and friendly way and I wish to express my special gratitude to her.

I am grateful to all the inhabitants of Nanga Dua Village for their hospitality, interest in and support for me and for my work. I admire their courage and knowledge. I will not forget their teachings. Special thanks must go to my host family: Ibu ${ }^{1}$ Maria, Bapak Simon and the children: Putrih, Sinta, Andika and Agustus. Thank you for making me feel at home in the heart of Borneo! Ibu Maria, Ibu Sodak, Nenek Lama and Nenek Bui were generous informants about their traditions. I would like to thank the four local field assistants: Bapak Dobet, Bapak Endan, Bapak Ovit and Bapak Lombok for their help and friendship. They were like caring big brothers to me; they never got tired of helping me and making me laugh. Bapak Dobet, my dear friend and the best storyteller in Nanga Dua kept a watchful eye on me and saved me from many dangerous situations. Thank you, Bapak Dobet.

I am grateful to Bayuni Shantiko, Bapak Wyiono, Bapak Rizali and Landung, who were great companions on the field. Special thanks to Bapak Rizali, who did a great job of identifying the plant species. I also would like to thank the CIFOR staff: Danan Hadi for being an untiring support in mapping and Tina Taufiqoh for her teachings.

Ariane Cosiaux, Thibaut Dos Santos, Anis Chakib and Nicolas Labrière were great travel mates and I hope their future paths will be blessed. Last but not least, I would like to express my gratitude to Cécile Lachaux, whose friendship during my stay in Indonesia gave me a lot of strength.

Finally I would like to dedicate this work to my family and friends - without them I would not have had the fortitude to go through this experience with such lightness and joy. 


\section{Introduction}

\subsection{Forests in Kalimantan: A changing environment}

Indonesia is blessed with an extraordinarily rich natural and cultural heritage. It contains $10 \%$ of the remaining global tropical rainforest, placing it in third place, after Brazil and the Democratic Republic of Congo (FAO 2010). These tropical forests house a high biological diversity and provide multiple goods and services. Deforestation for cultivating crops created radical changes during the last decades, resulting in a forest cover drop from 162 million hectares in 1950 (Global Forest Watch, 1995) to
94.4 million ha in 2010 (World Bank 2010; FAO 2011). This induces rapid habitat loss, threatening a high number of endemic species with extinction.

Southeast Asia had the highest deforestation rate among tropical regions in the world at the end of the 1990s (Miettinen et al. 2011). The Indonesian part of Borneo, called Kalimantan, covers an area of 54 million ha. In 2002, approximately $50 \%$ of this area, or 26.7 million ha, was still under forest, but this has been steadily diminishing due to deforestation (Fuller et al. 2004; Miettinen et al. 2011; Figure 1). A great number of species can be found in its different
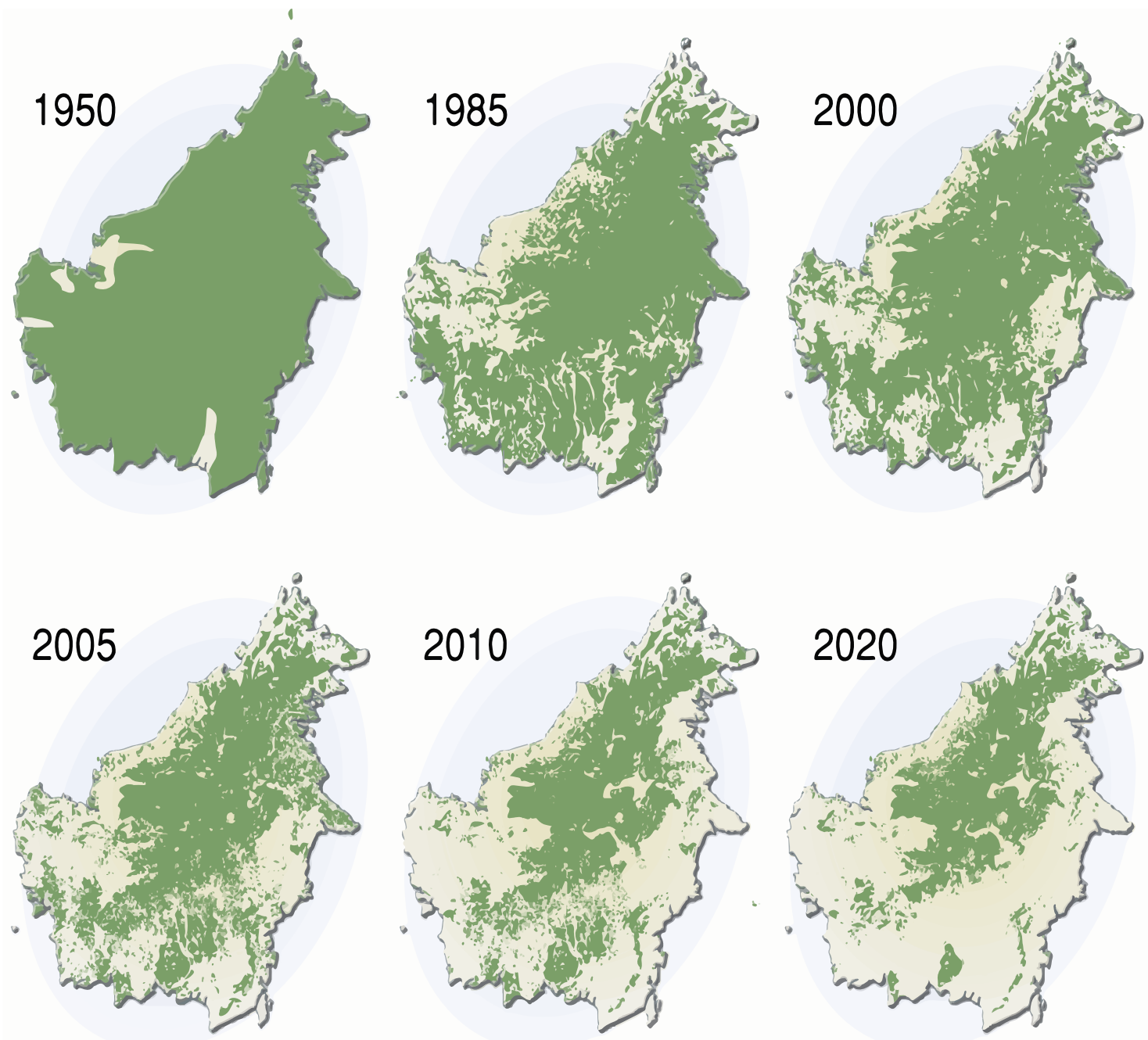

Figure 1. Deforestation in Borneo: Steady depletion of forest cover between 1950 and 2005, and projected loss up to 2020.

Source: Ahlenius (2007) 
forest types and habitats. Kalimantan is part of the Sundaland biodiversity hotspot, which means its ecosystems are a priority for conservation issues (Myers et al. 2000). Its forests are home to more than 3000 tree species, including 267 species of the Dipterocarpaceae ${ }^{2}$ family, of which 155 are endemic to Borneo (Ashton 1982). The lowland dipterocarp forest is one of the most species rich in the world in terms of flora and fauna (Whitmore 1988). It grows on mineral soils on altitudes under $<300 \mathrm{~m}$ or $<500 \mathrm{~m}$, according to the classification of different authors (Symington 1943; van Steenis 1972; Whitmore 1988; Laumonier 1997), where it gradually changes to hilly dipterocarp forest.

In addition to its natural richness, Indonesia's cultural heritage is extremely diverse. According to Istiyani (2008), there are 168 local dialects in the province of West Kalimantan ${ }^{3}$. All over the world, cultural diversity influences both natural resource management and natural diversity (Hill 2008). Numerous publications, such as the Millennium Ecosystem Assessment (2005), demonstrate the links between human well-being and ecosystem services. Directly or indirectly, the Indonesian forests are of great social, economic and environmental importance. The role they play for the national economy, as well as the livelihood of local communities is crucial.

\subsection{Indigenous-community-based forest management systems in Kalimantan}

The forests of Indonesia and their resources have been managed by indigenous groups for millennia using traditional knowledge and customary laws. These community-based practices differ from the management carried out by the government or industrial firms, as they are generally small-scale and based on diverse consumption and cultural needs. Cultivation usually evolves through swidden agriculture and the planting of selected plant and tree species. According to Kleinman et al. (1995), small-scale swidden agriculture is viewed as a sustainable practice, as smallholders are not dependent on "outside inputs based on fossil energy for fertilizers, pesticides and irrigation.” Agroforests cover 6-8 million ha in Indonesia and constitute a major income source for smallholders (Michon et al. 2005). The extracted products include: rubber latex,

2 Dipterocarpaceae is a family of tropical hardwood trees, dominant in Borneo (Appanah and Turnbull 1998)

3 Kalimantan has four administrative provinces: West, East, South and Central Kalimantan. dipterocarp and benzoin resin, spices, fuelwood, fruits, nuts, bamboo, handicraft material, and medicinal plants.

Hunting and gathering is still practiced in the interior of Borneo. Products extracted from the forest can be used for selling or self-consumption. In West Kalimantan, some Dayak ${ }^{4}$ communities gather agarwood (gaharu) a resinous substance that forms in the wood of trees, belonging to the Aquilaria genus, when they are infected with a specific fungus (Subehan et al. 2005). This resin is used as incense or in perfume, and is sold on the national and international market. An important source of income for Indonesian smallholders is the growing and tapping of rubber trees (Hevea brasiliensis) (Michon et al. 2005).

The agricultural systems of Kalimantan are traditionally based on swidden agriculture, as it is found in numerous Dayak villages (Jessup and Vayda 1988; Poffenberger and McGean 1993; Comptour 2011). As Kalimantan's soils are poor in minerals and nutrients, shifting cultivation is practiced in order to fertilize the soils through burning of trees (Setyawan 2010). The swiddens, called ladang, are fields grown with upland rice and a broad variety of fruits and vegetables (Gönner 2000; Crevello 2003).

The indigenous forest management systems and local resource uses have maintained human health and protected environments, and they may be a key to sustainability (Crevello 2004; Contreras-Hermosilla and Fay 2005; Sobrevila 2008). These systems are not static or unchanging, but adaptable, flexible and influential uses of diverse resources and natural dynamics (Jessup and Vayda 1988; Gönner 2002).

According to Michon et al. (2005) between 40 and 65 million people are forest dependent in Indonesia, but none of them have "any official tenure rights to the lands they manage or to the forest resources from which they make their living.' This highlights major threats for smallholders, who live and work on state forest land. The government allocates millions of hectares to timber, plantation and mining companies or declares non-exploitable conservation areas, with little or no regard to the needs of local communities. The challenge for Indonesia as a nation is to improve the management

4 'Dayak', meaning 'people of the upstream' (Joshi et al. 2004), is the general name for the indigenous people of Kalimantan. Dayaks have inhabited the island for the past 40,000 years (Jessup and Vayda 1988). 
of its remaining forests, in a manner that respects communities' rights and conserves environmental services (Contreras-Hermosilla and Fay 2005). A better understanding of the social, economic and environmental interactions at landscape level is needed in order to establish development versus conservation priorities and enhance the livelihoods of local people.

\section{The CoLUPSIA project}

In this context of rapid land use change and important land management issues theCoLUPSIA, Collaborative Land Use Planning and Sustainable InstitutionalArrangements project of CIRAD, funded by the European Union, was launched in partnershipwith CIFOR, TELAPAK and several local NGOs and Universities. Its aim is to contribute toavoid environmental degradation in Indonesia, and to strengthen land tenure and communityrights by integrating all stakeholders' views in rural land use planning processes (CIRAD2010, CIFOR 2012). The outputs revolve around the relationship between land use planningand the provision of ecosystem services, which may lead to payments for environmentalservices later on. The project focuses on two regencies (kabupaten), Kapuas Hulu and Central Maluku.

\subsection{Kapuas Hulu Regency}

This study is conducted in the regency of Kapuas Hulu, in the northeastern part of the West Kalimantan Province (Figures 2 and 3). The climate is equatorial, with over $200 \mathrm{~mm}$ of rainfall per month and average mean temperatures of over $20^{\circ} \mathrm{C}$ (Fontanel and Chantefort 1978; Oldeman et al. 1980). Trees mostly bear fruits during the wet season, from December to March (Galdikas 2009). Soils in the region are mainly ultisols (Palm et al. 2007).

Kapuas Hulu is called a "conservation regency" as it houses two large national parks and is the source of major rivers and streams. Covering a total surface of 2.9 million ha (BPS-Statistics 2010), the regency has lost 320,000 ha of forests to oil palm plantations (Persoon and Osseweijer 2008). According to vegetation maps established by the Collaborative Land Use Planning and Sustainable Institutional Arrangements (CoLUPSIA) team, approximately 1.8 million ha are still under primary forest cover.

With the improvement of the road network, the pressure of deforestation by further plantations and illegal logging may grow, putting the forests of Kapuas Hulu at further risk. According to Curran et al. (2004) lowland forests are particularly vulnerable, as they contain "distinctive dipterocarp habitats, the majority of vertebrates, the greatest canopy tree diversity, and the majority of land used by humans." In the province of West Kalimantan, the lowland dipterocarp forest has almost disappeared, except for the Kapuas Hulu Regency.

\subsection{Aim of this study}

The CoLUPSIA team conducted an extensive socioecological survey in the regency. Household-level socioeconomic surveys of 20 villages were carried out in 2011 in the northern part of Kapuas Hulu Regency, which are mostly occupied by Dayak Iban villages. Comptour (2011) studied the landscape and agricultural practices in Keluin Village. More data are needed for the southern and eastern part of Kapua Hulu Regency, where gold mining is known to occur. The landscapes of this area, a mosaic of mixed dipterocarp forest and kerangas ${ }^{5}$ forest, have not been described yet. The CoLUPSIA project focuses on a Dayak Mentebah village called Nanga Dua.

The aim of this study is to assess the local resourceuse systems and values related to vegetation cover and associated goods and services in the landscapes of Nanga Dua. A better understanding of the contribution of indigenous knowledge and land uses to biodiversity management is necessary for better planning of natural resource management.

The two main research questions are:

- How do people in a Dayak Mentebah village perceive and exploit their environment?

- To what extent is local plant diversity used in traditional practices, such as traditional medicine?

The objectives are to

- conduct a participatory survey with local farmers, which will highlight their landscape perceptions, the uses and the values they attribute to different species and land uses;

- evaluate the different land uses on a scientific basis and conduct ecological research by assessing tree diversity and vegetation structure;

- carry out a study on medicinal plants, in order to get a deeper insight into this traditional knowledge.

5 Kerangas, which in Iban language means "land that cannot grow rice," are heathly forests on sandy soils (Katagiriet al. 1991). 


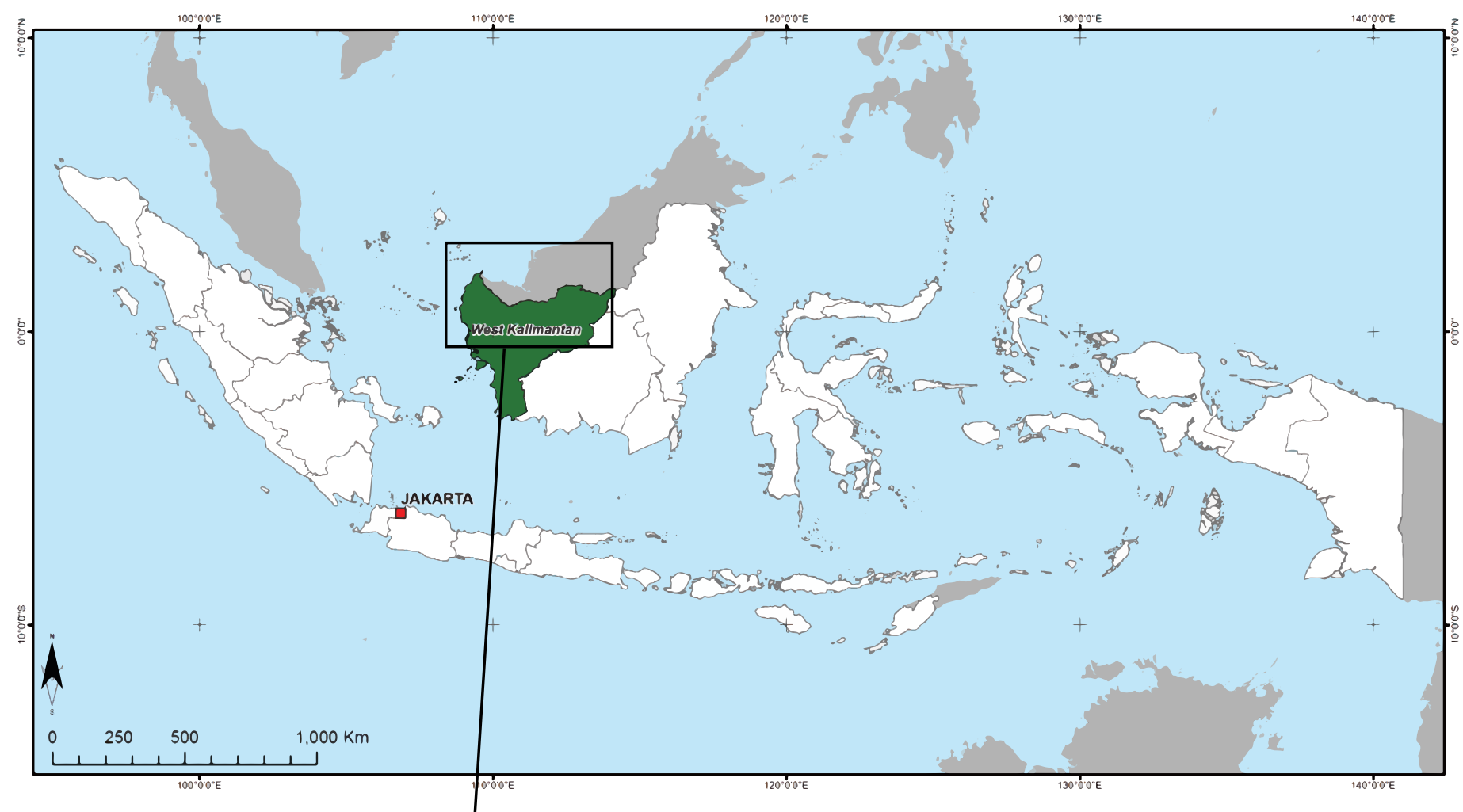

Figure 2. Location of the Indonesian province of West Kalimantan, in green.

Source: Adapted from maps established by Danan Hadi, CoLUPSIA

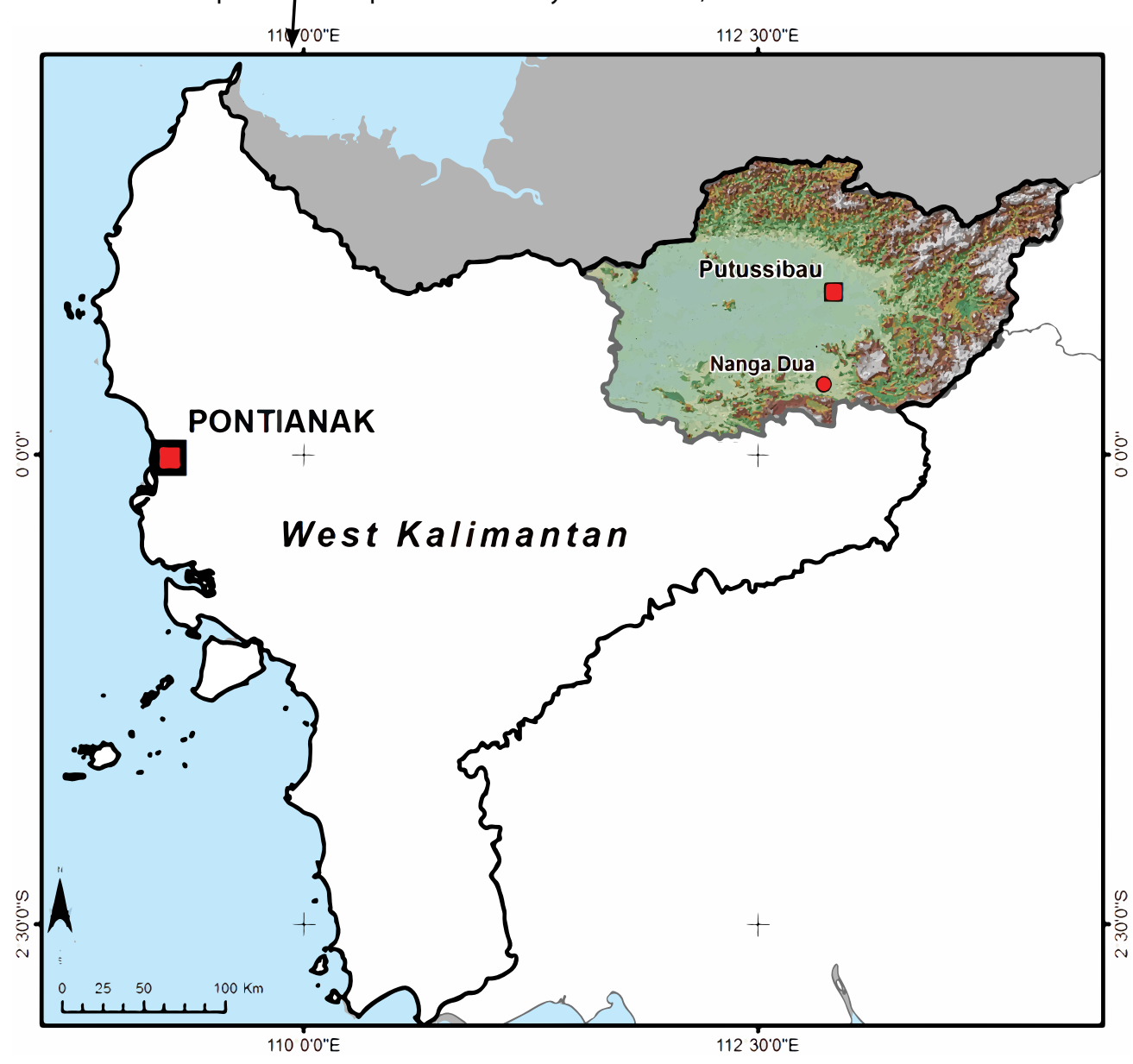

Figure 3. Location of study site. In color: the Kapuas Hulu district. Red dot: Nanga Dua Village, the study location.

Source: Adapted from maps established by Danan Hadi, CoLUPSIA 


\section{Materials and methods}

\subsection{The territory of Nanga Dua}

Nanga Dua Village is in Bunut Hulu District, where the Mentebah and Penungun rivers meet. These two rivers belong to important watersheds and a large number of tributaries meet them. Nanga Jerihai to the east is a hamlet belonging to Nanga Dua that was not included in this study. South of it, downstream, is the neighboring village of Nanga Payang. The villages and the rivers are at an altitude of under $100 \mathrm{~m}$. Low but steep hills, not higher then $200 \mathrm{~m}$ stretch north of Nanga Dua (Gunung Tahu). Overall, most of the territory is below $300 \mathrm{~m}$ in altitude, but to the south hills and mountains (Gunung Tuan) rise up to $1000 \mathrm{~m}$.

The map (Figure 4) established using Landsat satellite imagery gives a general overview of the territory, but it lacks accuracy due to dense cloud cover on the

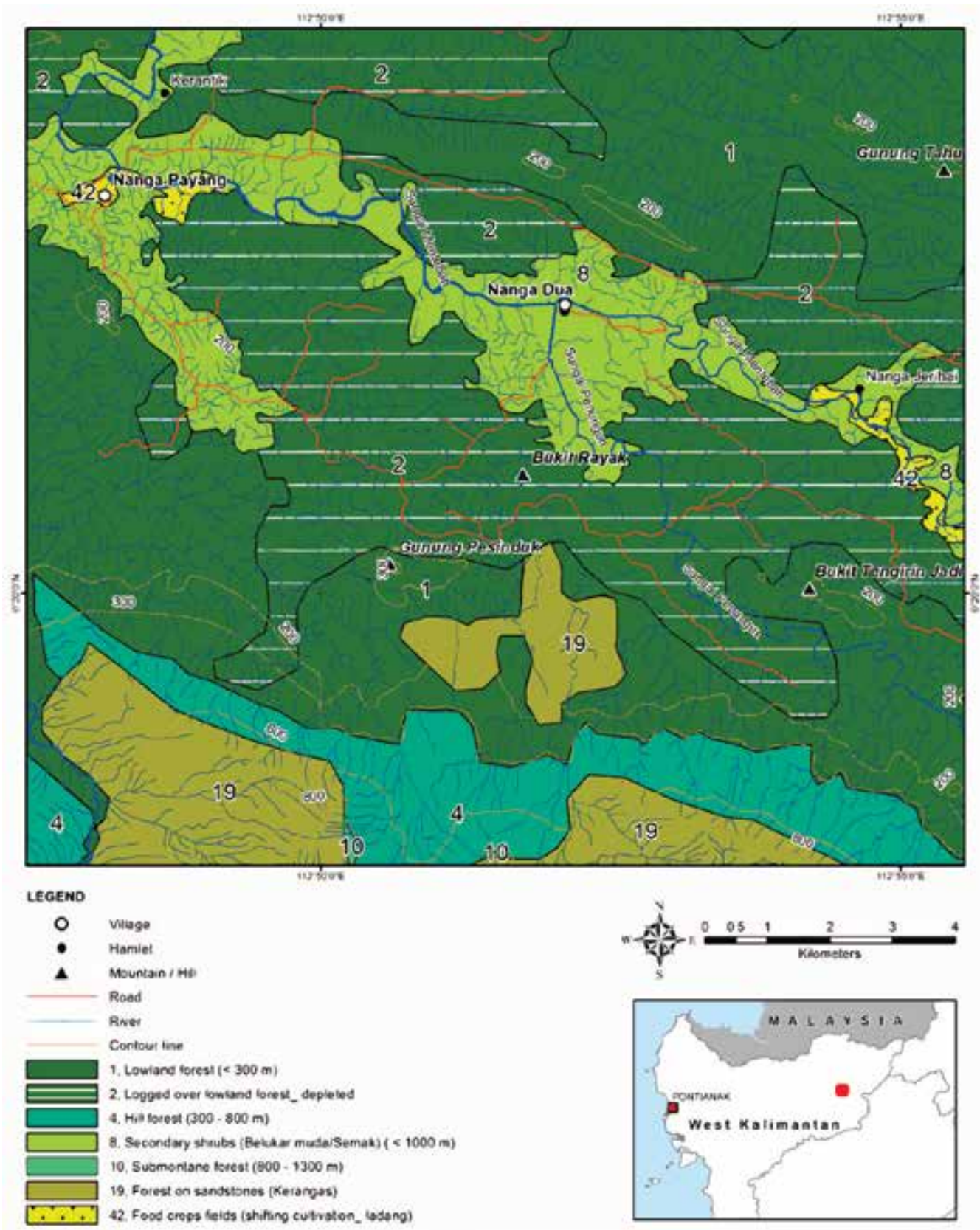

Figure 4. Vegetation map and localisation of the study site, established by CoLUPSIA using Landsat satellite imagery from 2009. 
pictures. The scale does not allow for much detail in terms of landscape and agricultural types. The section in bright green around the village and along the two main rivers refers to a mosaic of secondary regrowth, fallows and gardens. Logged over lowland forest stretches to the north of the area and south of River Mentebah. Further south, the forest seems unaffected by logging activities, giving way to intact lowland forest, which is replaced further up by hill forests (300-800 m of altitude). The kerangas forest, which developed on sandstone, occurs on hills south of the sector, mainly above $600 \mathrm{~m}$ altitude, and on an important section below $300 \mathrm{~m}$.

\subsection{Methods}

This study describes local people's interactions with their natural environment and refers to ethnobiology or the science of how people understand and use their environment, including plants and animals, based on their culture (Pieroni et al. 2005). The field survey was conducted over a 3-month period from April to July 2012. Preliminary preparation for the study included an intense course in the Indonesian language over a 2-week period.

This study examined three different crucial sources of information to obtain insight in peoples' perceptions and their environment: (i) knowledge gained through observing peoples' activities, (ii) knowledge provided by local people, and (iii) knowledge gained through scientific measurement (Lynam 1999).

\subsubsection{Participative observation}

One way of gathering information in ethnology is through talking with people, observing what they do and participating in their activities (Gerique 2006). Simple, informal questions and enquiry techniques such as semi-structured interviews (Martin 2004) confirmed the observations made. This was used as a first approach to gain a basic understanding of the activities, history and socioeconomic situation of Nanga Dua Village. Local experts were identified with the help of local people. These experts became key informants for the different research topics, such as forest types, tree diversity or medicinal plants. Interviews provided a way of creating a calendar of agriculture and other main subsistence activities.

\subsubsection{Perception of the land use, landscape and species value}

To get a deeper insight into the different land uses and the values the villagers attributed to the different landscapes ${ }^{6}$ and species, participatory research methods were used. People participated on a voluntary basis.

\section{Focus group discussions}

Two topics were examined with the villagers in focus group discussions (Kitzinger 2003). In the first session, 7 women and 1 man were asked to name and define the existing land types, in order to get an overview of the peoples' understanding of existing landscapes and land-use units. During the second meeting, composed of 11 women and 3 men, different categories of uses were defined. Lists were then established containing the most important species (local name), derived from the different land-use types, for each use category. In order to work in accordance with the villagers' understanding of the different landscapes and land uses, the established classifications were subsequently used for all further surveys, such as the pebble distribution method (see below).

\section{Community landscape mapping}

Community mapping is a powerful tool to localize the different landscapes, vegetation cover type and the associated specific uses, as viewed by local people (Chambers 1994; Corbett 2009). As well as a base map containing the main rivers and paths, villagers were asked to draw the borders of their territory, the natural resources, the different types of land and the related uses, such as fallows, protected areas, etc. For efficiency, symbols for the different land uses were created before the meeting, in accordance with the land-type classification established by the villagers during the focus group discussion. To ensure that women expressed themselves freely, men and women were divided into two different groups of four people each and each group was consulted separately.

\section{The pebbles distribution method (PDM) or scoring exercise}

The pebbles distribution method (PDM) or scoring exercise helps to assess the "importance" of biodiversity to people who rely on natural resources (Carol et al. 1999; Sheil et al. 2003). The method was used during two meetings, one with eight women and one with seven men (Photo 1).

Importance of the land types for use categories To understand which types of land are valued for what kind of use, informants were asked to distribute 100 pebbles on illustrated cards, representing the different types of land units,

6 The different types of vegetation cover are refered to as landscape units or land-use units 


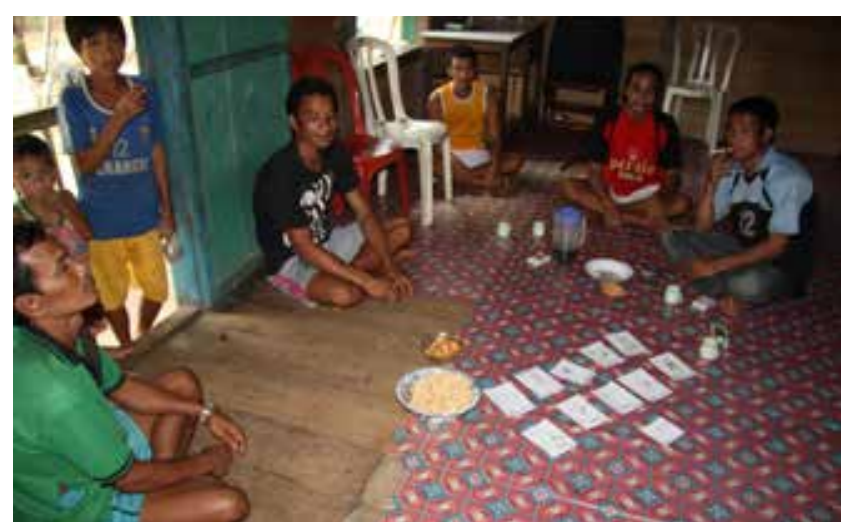

Photo 1. Some of the men during the scoring exercise. (Photo by Edith Weihreter.)

according to their importance in terms of different resource-use categories. In order to facilitate understanding, the resource-use categories were also drawn on cards (Photo 2). A high number of pebbles placed on a card means that a high value is given to this land unit and vice versa.

\section{Income}

The PDM was also used to assess the value of each type of land use with regard to income. The participants were asked to place the pebbles on the land unit cards according to their relative importance with regard to income. The informers were asked to name income-generating products and species and their price.

\section{Past-present-future}

In a context of rapid land-use changes, it was important to enquire about changes in perception over time. The overall importance of the landscape units 30 years ago, now and in 20 years time was evaluated. The villagers were asked to distribute the pebbles on the cards for the present, the past and the future. The data was analyzed using Excel to produce graphs and facilitate visualization of the results.

\subsubsection{Medicinal plant use}

An additional study was conducted in order to gain knowledge about traditional plant use of the villagers. The choice of the key informants was restricted mainly to women, as men were not present in the village much during the daytime and social constrains forbade field excursions with one man only. Three men were questioned during expeditions in the forest. Among the six surveyed women were three key informants, who are acknowledged as experts in traditional healing practices. Ibu Maria (48 years old), the wife of the village chief Bapak Simon, is consulted by many villagers for all types of diseases. Nenek Lama and Nenek Bui (both around 70 years

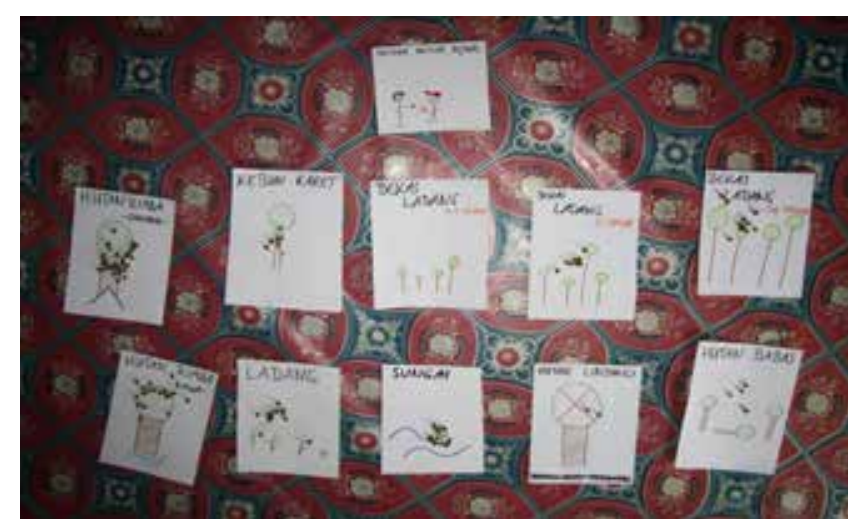

Photo 2. Example of PDM: Importance of the land types regarding products for selling. (Photo by Edith Weihreter.)

old) help women to give birth. The womens' home gardens were studied in detail as they plant medicinal plants close to their houses.

During daily field excursions, wild medicinal plants were gathered and conserved in ethanol. This herbarium collection enabled scientific identification of most of the species at CIFOR headquarters, Bogor ${ }^{7}$. The location, local name, use and route of administration were recorded for each plant. When a person became ill, the healing procedures used by Ibu Maria were observed and discussed with her.

\subsubsection{Ecological analysis of the different land use units through tree diversity}

In order to make the link between the resource management systems of the villagers and the forest environment, the tree diversity found in the different types of land-use areas was assessed. The following seven areas were studied: logged-over forest; fallows of 5, 15 and 30 years old; and three types of primary lowland forests: swamp forest, hill forest and the kerangas (Table 1). The focus group discussions, community maps and suggestions of the key informants enabled us to choose the study sites according to the different land and resource uses.

\section{Data collection}

For each land type, one plot enabled sampling of 0.2 ha of vegetation, using five small $20 \mathrm{~m} \mathrm{X} 20 \mathrm{~m}$ subplots (Figure 5) per type (swamp, hill, kerangas, logged-over dipterocarp forest and the three age classes of fallows). Seven of these plots in the seven different land-use units were analyzed, which corresponds to a total area of 1.4 ha. Within the scope of another CoLUPSIA vegetation assessment in the swamp, hill and kerangas forests, 10 of these survey plots included

7 All scientific names of the collected medicinal plants and trees were verified using The Plant List (2010). 
Table 1. Plot site description.

\begin{tabular}{llc}
\hline Land unit type & Local name & Mean altitude of plot sites (m) \\
\hline Lowland swamp forest & hutan rimba rawa & 75 \\
\hline Hill forest & hutan rimba gunung & 300 \\
\hline Forest on sandy soil & kerangas & 200 \\
\hline Logged-over forest & hutan babas/sudah ditebang & 70 \\
\hline Fallows (5, 15 and 30 years old) & bekas ladang & 70 \\
\hline
\end{tabular}

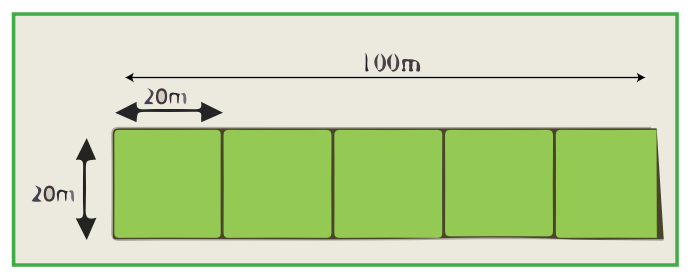

Figure 5 . Setting of the 0.2 ha plots used in the fallows and logged-over forest.

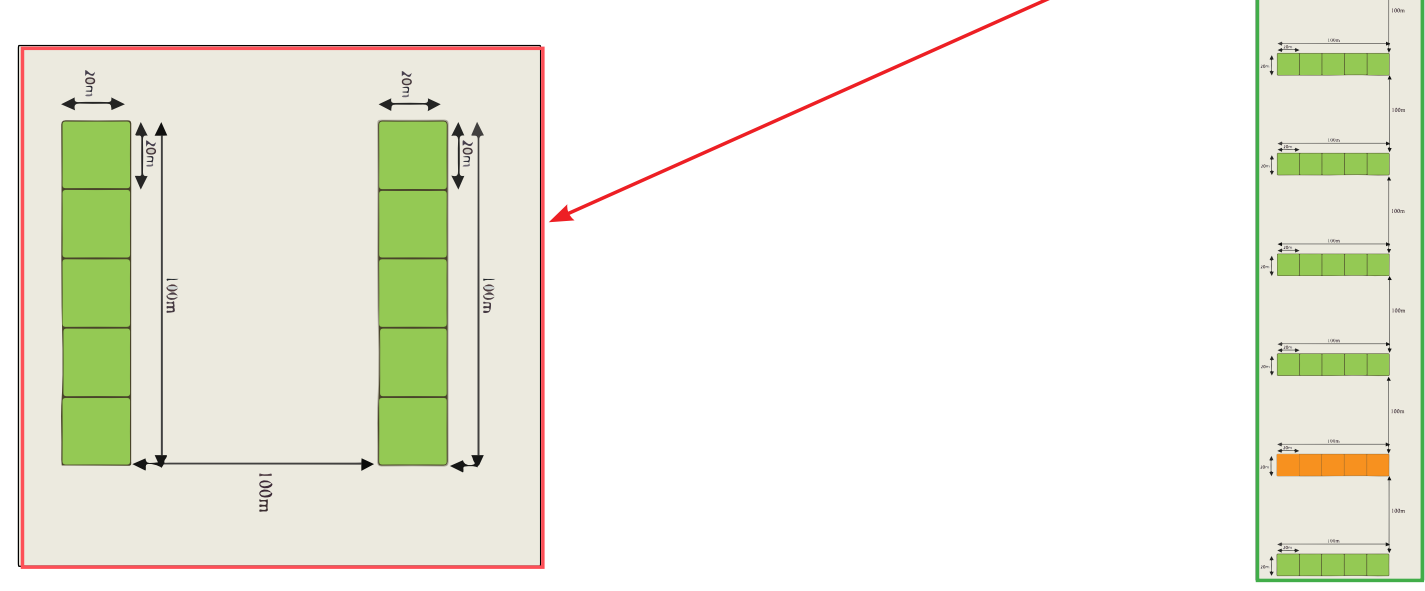

Figure 6. Zoom on 2 out of 10 plots laid in a row in the lowland hill forest as well as the kerangas. The orange plot symbolizes the plot which was randomly choosen for this study.

a total of 3 areas of 2 ha each. Between each of the 10 plots, a distance of $100 \mathrm{~m}$ was established (Figure 6). Out of these 10 plots, one data set of one plot was chosen randomly and used in this study, in order to compare the data from the swamp, hill and kerangas forests with the data sampled in the fallows and logged-over forest.

For each plot, leaf samples of each tree species were collected and their local name was recorded, which allowed scientific identification at CIFOR, Bogor. A field herbarium folder with dried leaves of each species was made to crosscheck every local name with the key informants in the village.

In each plot, the diameter at breast height ( $\mathrm{dbh}$ ) was measured $1.3 \mathrm{~m}$ from the ground or above trunk deformations, for each tree that had a diameter $\geq 10 \mathrm{~cm}$. The dbh was measured using a diameter tape, which gives diameter values in centimetres. If the tree had a high buttress, ladders or lianas were used to climb the tree and measure the diameter above the buttress (Photos 3 and 4). As these are permanent plot sites, each tree was numbered with a metal plate. The point at which diameter measurement was taken was marked by painting the trunk with a white line (Photo 5).

Four local field assistants were hired. Bapak Endan and Bapak Ovit were excellent tree climbers and gathered the leaves for the specimen collection. Bapak Dobet was the most knowledgeable about tree species and Bapak Lombok helped with the establishment of the plots. 


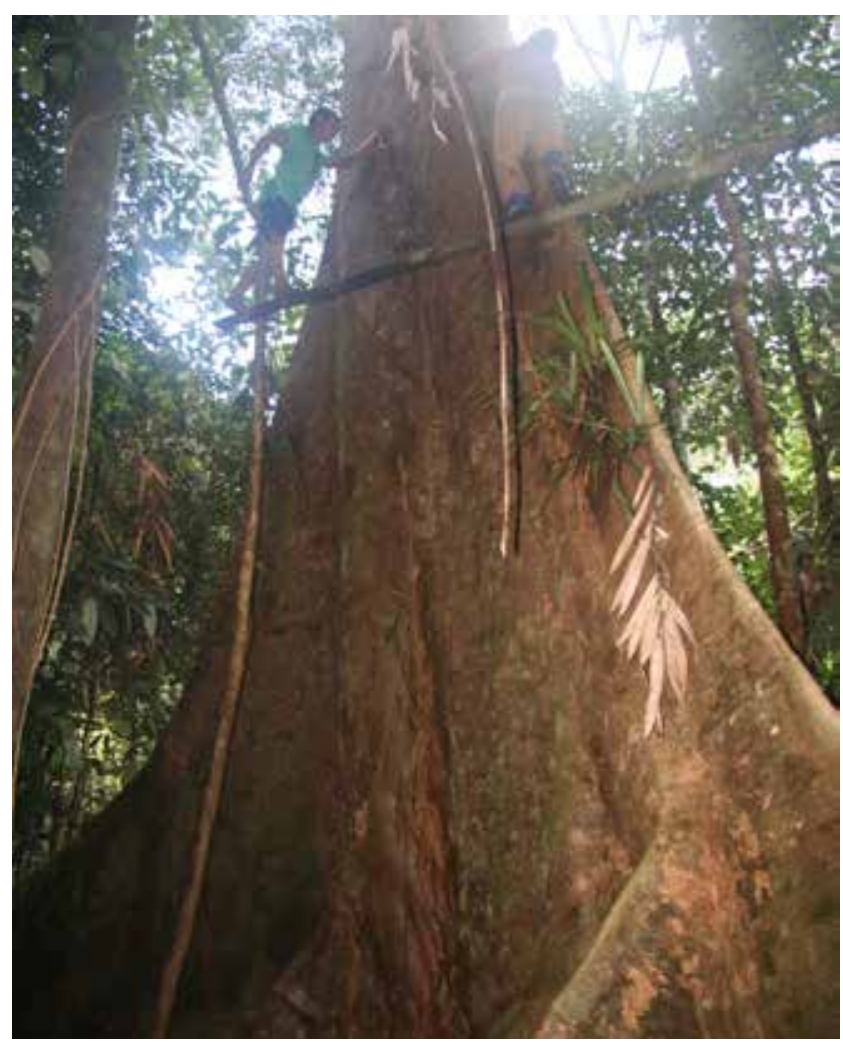

Photo 3. Bapak Endan and Lombok climb a tree with huge buttress for dbh measurement. (Photo by Edith Weihreter.)

\section{Data analysis}

- Overall species richness and distribution of $\mathrm{dbh}$ classes:

- The total number of species per land unit is used as first indicator for overall species richness. In order to get an insight of the sizes of the trees in the different land units, the distribution of $\mathrm{dbh}$ was evaluated using the following six classes: $10-20 \mathrm{~cm}$, $20-40 \mathrm{~cm}, 40-60 \mathrm{~cm}, 60-80 \mathrm{~cm}, 80-100 \mathrm{~cm}$, $100-185 \mathrm{~cm}$. These analyses were conducted using Microsoft Excel.

- The $\alpha$-diversity value D using the Simpson Index (Simpson 1949):

- The Simpson index $\lambda$ is used to measure the strength of species' dominance for each vegetation type. $\lambda$ has the following formula: $\left[\lambda=\sum \mathrm{n}(\mathrm{n}-1) / \mathrm{N}(\mathrm{N}-1)\right]$, where $\mathrm{n}$ is the total number of individuals of one species and $\mathrm{N}$ the total number of all individuals.

- In order to represent the $\alpha$-diversity ${ }^{8}$

$\mathrm{D}$ found in each plot site, the formula $[D=1-\lambda]$ is applied, according to Sagar and Sharma (2012). The index D ranges from 0 to 1 and expresses the probability that two

$8 \alpha$-diversity refers to species diversity found on a local scale, here the plot sites, whereas $\beta$ and $\gamma$-diversity refer to landscape and macro-scale (Whittaker et al. 2001)

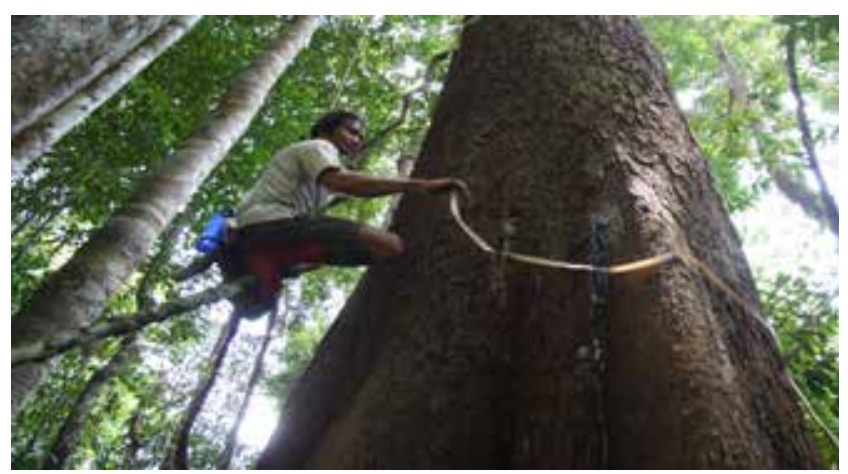

Photo 4. Bapak Ovit climbs a liana to ensure dbh measurement above buttress. (Photo by Edith Weihreter.)

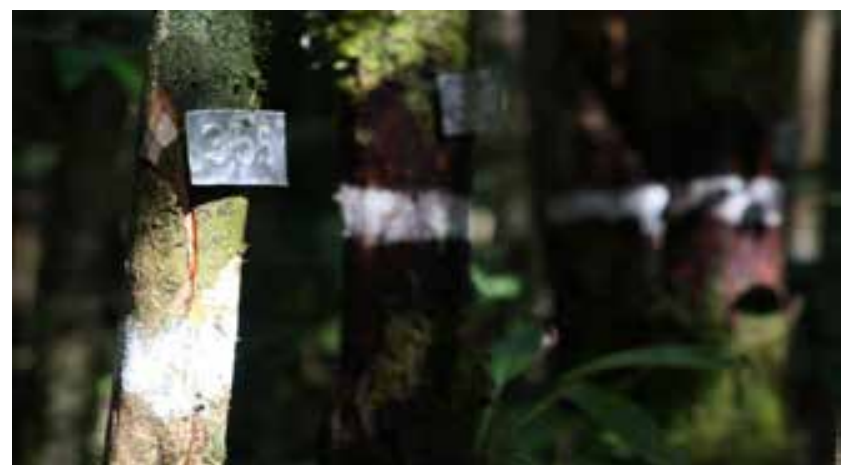

Photo 5. Number plates and white marks on sampled trees. (Photo by Edith Weihreter.)

individuals randomly selected from a sample will belong to different species. If $\mathrm{D}=0$, there is no diversity, which means only one species is present, and if $\mathrm{D}=1$ the species' diversity is at its maximum.

- Importance value index (IVI):

- IVI indicates the overall importance and dominance of a species in each plot site. It is calculated through summing the relative density (RDs) and the relative basal area (RBAs) of each species (Curtis and Cottam 1962) (see Table 2). It ranges from 0 to 200 , and the larger the IVI, the more dominant a species is in the land unit. After calculations are completed, species are ranker from high to low IVI in order to compare the land units with each other.

\subsection{Free listing of trees and medicinal plants}

\section{Data collection}

In order to assess the knowledge about trees and medicinal plants of a broader spectrum of villagers, individual interviews were conducted. The people were asked to name 15 species of trees, to explain what kind of uses they had for them and where they usually found them. The same question was used to assess the 
Table 2. Calculations for the importance value index according to Curtis and Cottam (1962) and Hédl et al. (2009).

\begin{tabular}{|c|c|c|}
\hline Relative density (RDs) & $=$ & (Number of individuals of one species / total number of individuals) $\times 100$ \\
\hline \multirow[t]{3}{*}{ Relative basal area (RBAs) } & $=$ & (Total basal area for one species / total basal areas of all species) x 100 \\
\hline & & Where the individual tree basal area in $\mathrm{m} 2$ is: \\
\hline & & $\mathrm{BAi}=\pi(\mathrm{dbh} / 2) 2 \times 10-4$ \\
\hline Importance value index (IVI) & $=$ & RDs + RBAs \\
\hline
\end{tabular}

villagers' knowledge about medicinal plants, including the route of administration (Appendix 1). This approach provides us with an idea of what species is culturally important to a person (Borgatti and Halgin 1998) and what species the villagers know best or use generally most. The informants were randomly chosen among 10 men and 10 women. For each age class $(<30,30-45,45-60,>60$ years old $) 2$ to 3 men as well as women were questioned, in order to represent all ages of the society.

\section{Data analysis}

The overall percentages of answers was calculated by summing the lists' lengths of each gender and topic group and dividing it by 150 , which is the total number of possible answers (10 participants X 15 species each).
Using the program ANTROPAC (Borgatti, 1992) the difference in species quoted between the different gender and age groups was analyzed. ANTROPAC enables to calculate the Smith's index of salience (Smith $S^{9}$ ). It highlights the psychologically or culturally important tree and medicinal plant species and differentiation in species choice and the degree of importance according to gender. Species with the greatest salience are those that respondents list the most often and tend to recall before other species (Borgatti and Halgin 1998). Smith S does not only put statistic weight on the rank of each species in the list, but also the overall length of each list (Balée 2010). Species that were named by at least two informants were considered and the 10 highest Smith $S$ values for the men as well as the women lists analyzed were recorded. 


\section{Results}

\subsection{Activities, history and socioeconomic situation of Nanga Dua}

The area has been inhabited for centuries, but the village was formally established in 1984, and currently has a population of 490 inhabitants. Due to an increased number of villagers, the traditional longhouse architecture was abandoned and people now live in individual houses, regrouped into one or more households (Photo 6). Access to the village is either by boat or through a former logging road by motorcycle. Travel time depends on rainfall. When it does not rain for a few days, most of the rivers and creeks become too low for navigation. When the rain is heavy the dust road becomes too muddy for motorcycling. Due to very high transportation $\operatorname{costs}^{10}$, the inhabitants are relatively isolated. They rarely or never go to see a doctor for disease treatment or vaccination and rely mostly on traditional medicinal plant treatment.

There are a few shops in the village with relatively expensive non-cultivated necessities such as soap, toothbrushes, petrol, etc. The village has a primary school with 75 children, aged from 6 to 13 years. From a socioeconomic survey conducted by the CoLUPSIA team in April 2012, it became evident that the educational level is generally very low and

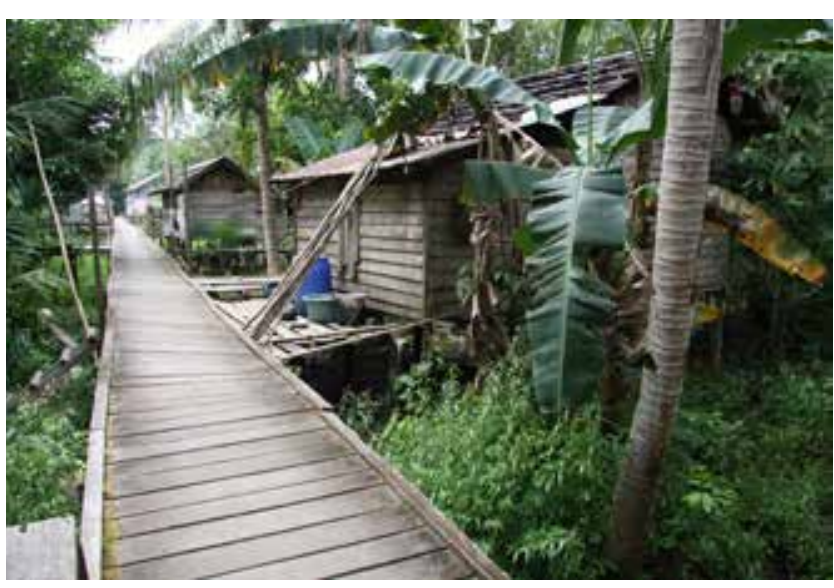

Photo 6. Some houses of Nanga Dua. (Photo by Edith Weihreter.)

in many cases primary school is the only education that children receive.

Agriculture, fishing, hunting ${ }^{11}$ and gathering is mainly done for subsidence. The villagers' agricultural system is based on annual swiddens. Traditional land tenure rights are family-based. New fields are opened every year using the slash-and-burn technique. Rotation is made on ancient fallows or on new soils that are cleared in primary forest. The detailed calendar of

\begin{tabular}{|c|c|c|c|c|c|c|c|c|c|c|c|c|c|}
\hline & & January & February & March & April & May & \begin{tabular}{|l} 
June \\
\end{tabular} & July & August & September & October & November & December \\
\hline \multirow{8}{*}{ 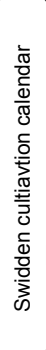 } & Rice harvesting & & & & & & & & & & & & \\
\hline & \multirow{3}{*}{$\begin{array}{l}\text { Clearing and culting of } \\
\text { ne's swidden site }\end{array}$} & & & & Primary fo & & & & & & & & \\
\hline & & & & & & Fallow 10 & 30 yrs old & & & & & & \\
\hline & & & & & & & & Fallow 1 - & 10 yrs old & & & & \\
\hline & Burning & & & & & & & & & & & & \\
\hline & Rice planting & & & & & & & & & & & & \\
\hline & Planting other plants & & & & & & & & & & & & \\
\hline & Weed control & & & & & & & & & & & & \\
\hline \multirow{6}{*}{ 㐫 } & Hunting & & & & & & & & & & & & \\
\hline & Gold-seeking & & & & & & & & & & & & \\
\hline & Rubber tree tapping & $\cdots+\cdots \cdots$ & $\cdots \cdots-D_{1}$ & y days only & $\ldots+\ldots-\ldots$ & $\ldots \ldots \ldots$ & ……........ & $\ldots . .$. Dry sf & eason & $\ldots+\cdots+\cdots$ & $\cdots \cdots \cdots$ & Dry days on & $y \cdots \cdots \cdots \cdots$ \\
\hline & Gathering firewood & & & & & & & & & & & & \\
\hline & Basketry & & & & & & & & & & & & \\
\hline & Gawai Dayak & & & & & & & & & & & & \\
\hline
\end{tabular}

Figure 7. Calendar of swidden agriculture and other activities.

10 Petrol costs IDR 12,000/l, compared to IDR 4500/l in Jakarta. Travelling to Putussibau (next hospital) costs around IDR 1,000,000 IDR ( $€$ € 86).
11 Men hunt using handmade rifles, and the gunpowder is made out of the wood of kayu tomau (Syzygium cymosa). 
activities is given in Figure 7. Women help each other to clear the new fields in exchange for salary. Basketry is a frequent practice and people commonly use plaited baskets, bags, mats or fish traps (Appendix 2). Trading of these items is done among villagers.

Most income comes from gold mining, which is done throughout the year. It is a unstable source of money. Gold is exclusively extracted out of River Mentebah and forbidden on River Penungun and all creeks. Gold mining activity has largely destroyed the aquatic flora and fauna of River Mentebah, due to an increased amount of floating sediments (Photo 7). Mercury use to amalgamate the gold dust requires the consent of the people of the other villages close to the river, as locals living downstream fish and bathe in its water. Inhabitants of Nanga Dua use River Penungun for drinking, toileting, bathing and washing clothes.

Men gather gaharu in the forest, which is extracted from Aquilaria microcarpa (gaharu bukit) or Aquilaria beccariana (gaharu pantai) trees, to sell in the village or in nearby markets (Semangut or Mentebah). Due to time-consuming gold mining activities, only a few people grow and tap rubber trees. While women mostly work in the village, swiddens or gold-mining camps, men wander far out into the forest in order to hunt or gather gaharu. People commonly complained that the surrounding forests are "emptied" of animals, such as wild boar, birds or apes, and that prices for meat within the village steadily rise, as hunters have to walk further. All adult respondents agreed that when they were children, animals could be found in abundance close to the village, but now hunting pressure has drastically reduced their numbers.

\subsection{Perception of the land use, landscape and species values}

\section{Focus group discussions}

The villagers defined eight main types of land-use units (Figure 8) during the first meeting: primary swamp forest (hutan rimba rawa), primary hill forest (hutan rimba gunung), logged-over forest (hutan babas), "protected" forest (hutan adat, tidak boleh ditebang ${ }^{12}$ ), swidden (ladang), fallow (bekas ladang), rubber garden (kebun karet) and the rivers (sungai).

Hutan rimba is referred to as primary, "untouched", forest in English, although some trees might

12 In English: forest you are not allowed to cut, according to traditional law $(=a d a t)$

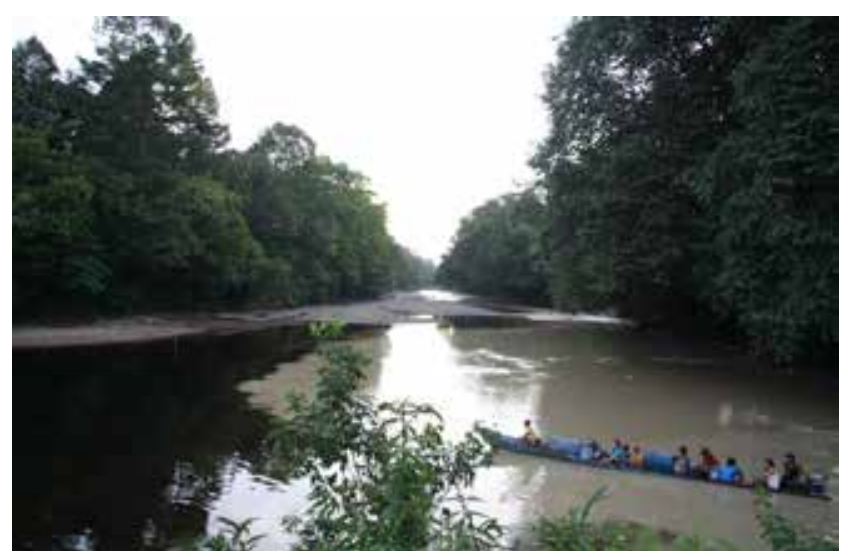

Photo 7. River Penungun to the left and river Mentebah to the right, loaded with sediment. (Photo by Edith Weihreter.)

have been extracted by villagers 50 or more years ago. The primary swamp forest occupies small depressions at the foot of the hills, with a large number of small rivers and creeks. Thirty years ago, a Malaysian company selectively extracted trees out of the lowland forest, creating the logged-over or secondary forest and the earth road. Villagers also extract timber and wood on a much smaller scale for housing, mining camps or boat construction. Due to fear of erosion or because the soils are too nutrient poor for agriculture, villagers do not cut trees in certain areas. These "protected forests" correspond with zones covered by kerangas forests. Although the villagers seem not to include them as a distinctive land-use unit in their categorization of the landscapes, they recognize kerangas as a different forest type. Swiddens are agricultural fields cleared and planted with rice, vegetables, fruits and medicinal plants for one year, before a new field is opened. Fallows are old swiddens, which are left fallow for soil recovery for a certain amount of years. Once the farmers estimate that the soils are ready, which may take up to 30 years, fallows are converted to swiddens again or rubber gardens. The current rubber trees are still young, at around 1-15 years old. As rivers represent an important food (fish) and income (gold) source, they were also named as a main land-use type.

During the second meeting nine land-use categories (Figure 9) were registered. The list of important animal and plant products for each of these categories totaled 110 species, of which 74 were gathered in primary forest, 24 in the swiddens and 12 in fallows. Four different species of gaharu were, for example, named as marketable products (Appendix 3). In this section rubber was not mentioned by the villagers. The category containing the highest amount of species was: hunted wildlife (with 29 animals mentioned) followed by food and medicinal plants. 


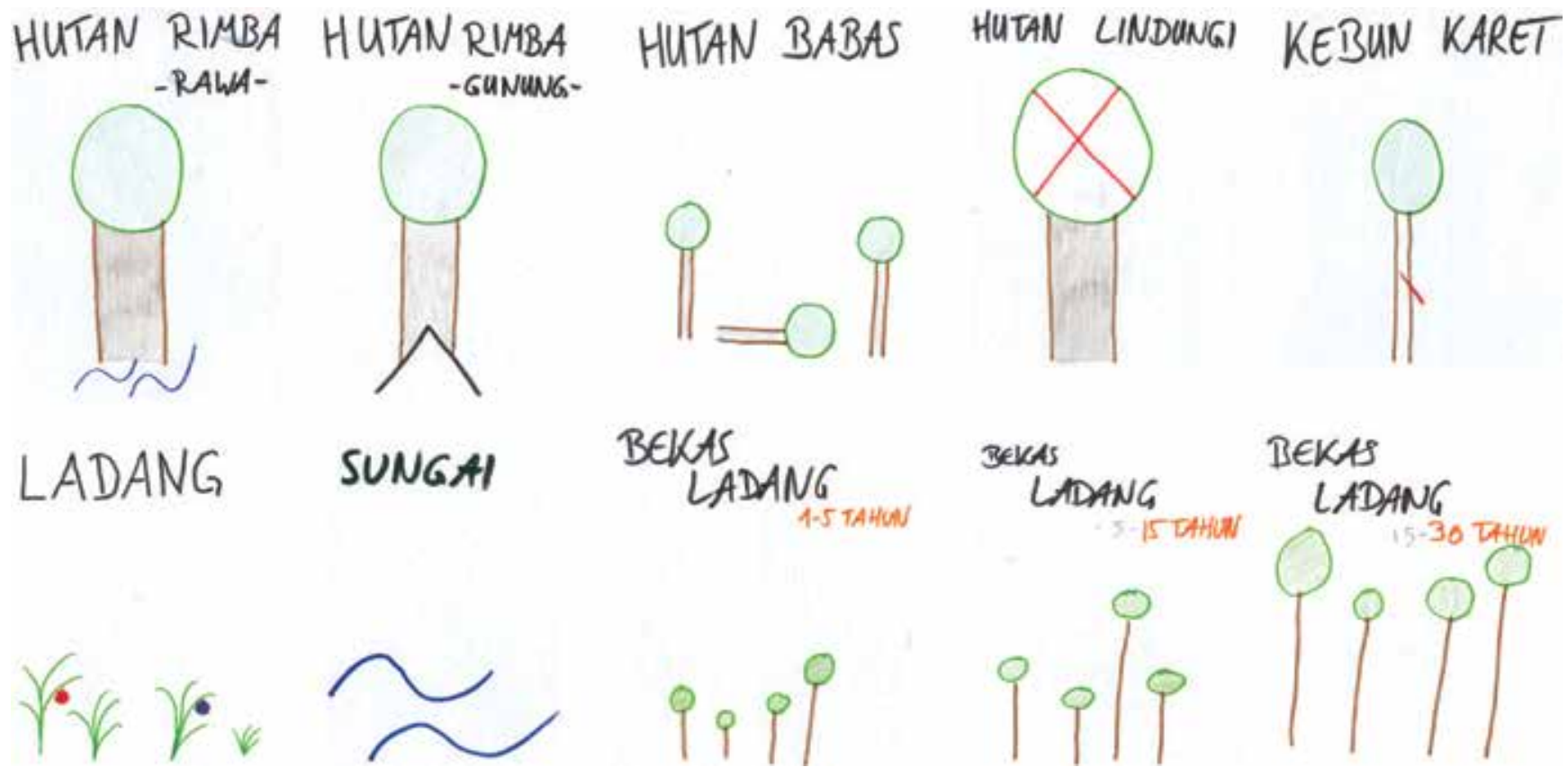

Figure 8. The eight land-use units established during the focus group discussion, cards used for the PDM. Here, fallows (bekas ladang) were differentiated according to their age (1-5, 5-15 or 15-30 years old).

MAKANAN

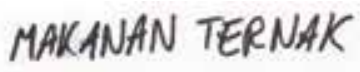

ANYAMAN

KONSTRUKSI

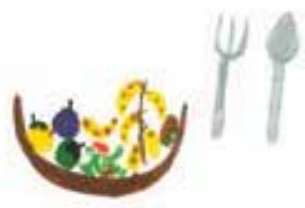

KAYU BAKAR

BINATANG / BERBURU

OSAT-OBATAN

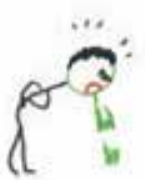

\section{RUMAH}

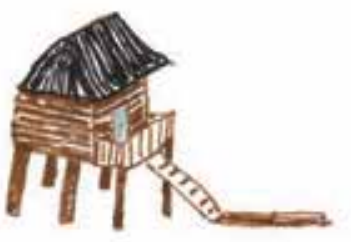

PRODUK UNTUK DJUAL

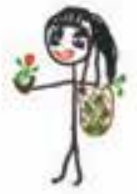

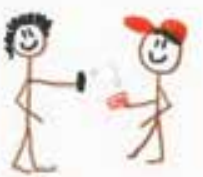

Figure 9. The eight land-use categories established during the focus group discussion, cards used for the PDM. 

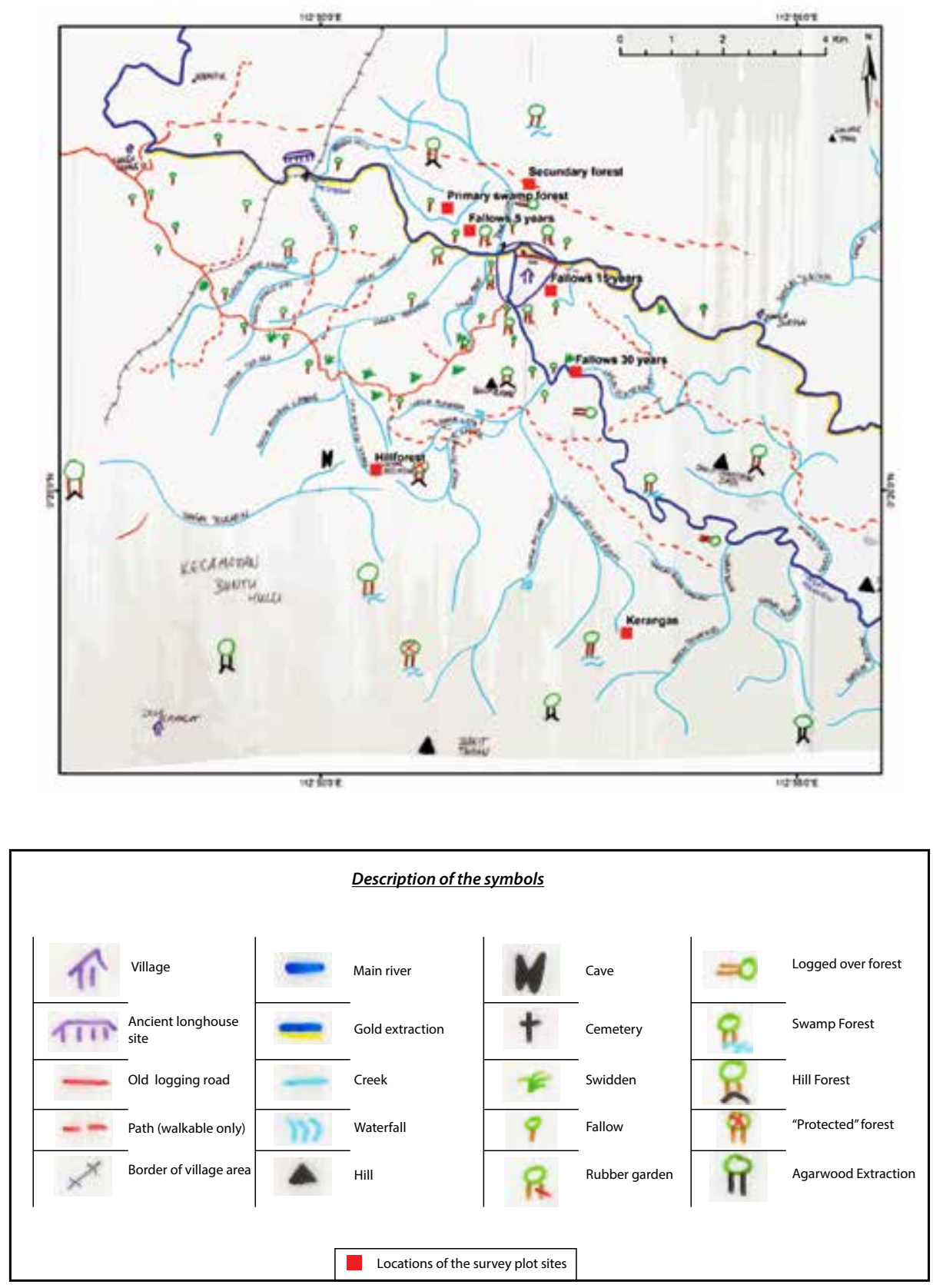

Figure 10. Map of the land types and land uses constructed by the men group.

\section{Community landscape mapping}

The men created a map that was more precise and correct in terms of distances and localizations then the women's map. The gap in territorial knowledge between men and women, highlighted through the participatory mapping process, reflects some of the realities of the women's world. Women do not have as much knowledge of the landscape as men as they spend more time in the village, while men wander far out into the forest, sometimes for months. This creates very different views of the environment.

The map established by the men (Figure 10) shows that the swiddens of this year were planted along the old logging road. The farthest field is a 3 hour walking distance (approximately $12 \mathrm{~km}$ ) from the village, alongside the border of the village Nanga Payang area. This logging road is the only land connection to the district's road network, as it is the only path which is drivable by motorcycle. The main walking paths are included on the map; apart from these the forest has a dense network of small, temporary hunting paths. The fallows lie around the village and the two main rivers. The rubber gardens are close to the village and are easily accessible by boat. The territory has many small rivers and only some were incorporated into the map. Most of the area is occupied by hill forest. Gaharu is exclusively 
gathered on Bukit Tuhan, the mountain range south of the territory, which contains mainly Keranga forests. It is accessible by boat and by walking through difficult and very steep terrain ( 1 or 2 days travel). The area contains one cave, inhabited by a small population (around 50 birds) of cave swiftlets (Aerodramus fuciphagus). The edible nests are not exploited by people of Nanga Dua, but exploitation rights are rented to people of Nanga Payang.

The red squares were added to the map later to indicate the location of the tree diversity survey plot sites.

\section{PDM scoring exercices}

\section{Importance of the land types for use categories}

Two graphs (Figure 11) represent the relative importance of the different land-use types for each land-use category, with respect to the data (Appendix 4) collected during the meetings. Generally, men tended to place either very large or very small amounts of pebbles on the landuse cards, while women distributed the pebbles more evenly. The importance men accorded to the different land-use types seems to be more contrasted. Both men and women expressed a preference using the pebbles for the hill forest, for all the use categories, except for fodder. Since it is forbidden to cut trees, the "protected" forest area falls into a less important category. The only use women had in this type of forest is for gathering medicinal plants and men used this forest for hunting. The rivers and swiddens were important for providing a food supply. Women found rubber gardens were also crucial in this category of use, while men negated this land type. Women seem also to have more use for swiddens, while men only thought of them as fodder and food sources, women gather fuelwood and medicines there.

A close-up look on the land-use category "medicinal plants" (Figure 12) reveals that women placed pebbles on the land types and men placed them
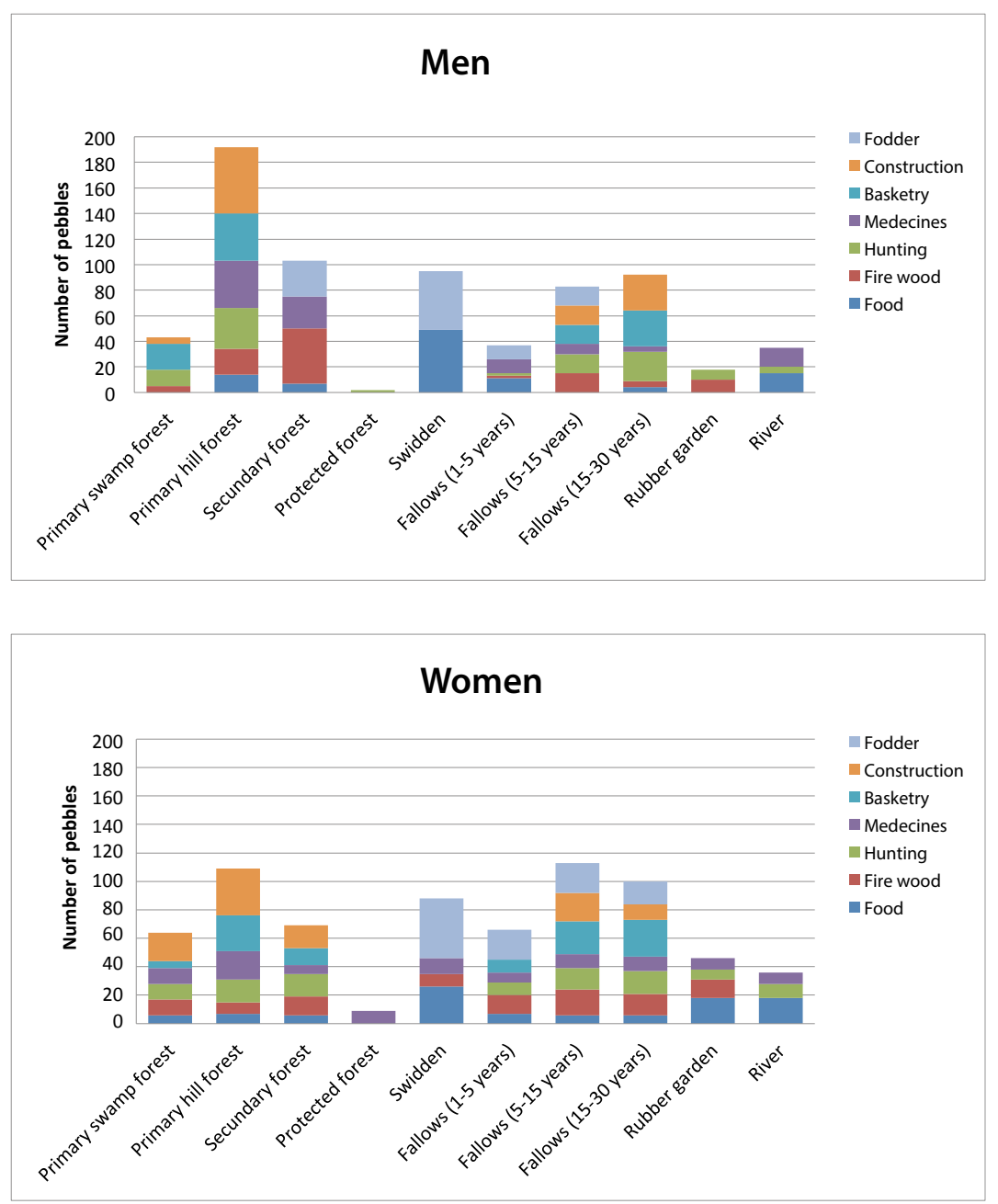

Figure 11. Importance of each land unit with regard to different use categories (men and women groups). 

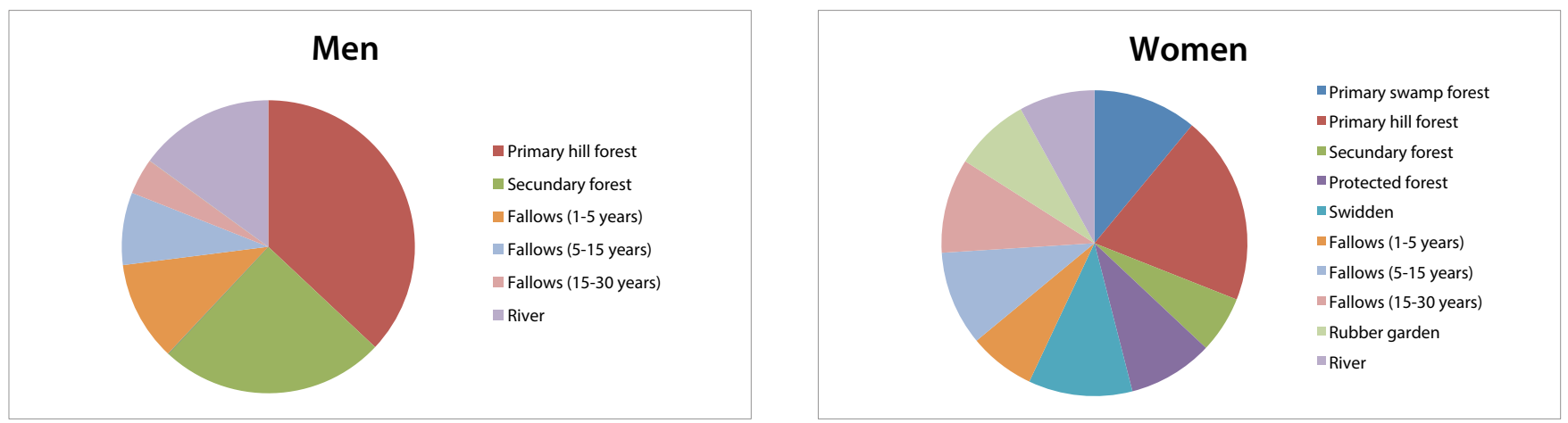

Figure 12. Importance of each land unit regarding medicinal plants (men and women).

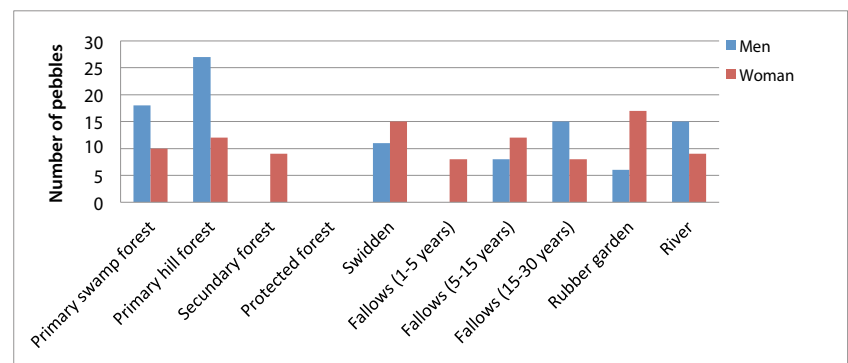

Figure 13. Importance of land-use types with regard to income.

on six different land types. Men argued that no medicinal plants are to be found in swamp forest, swiddens, rubber gardens and "protected" forests. Women recognized that medicinal plants are gathered in each land unit. It can be deduced that woman gather medicinal plants in more landscape units then men.

\section{Income}

While men placed a high value (Figure 13 and Appendix 5) on primary hill and swamp forest for their income, women found rubber gardens and swiddens more valuable. In contrast to women, men did not find secondary forests and fallows of $1-5$ years old important for income. Both groups scored the "protected" forest as being not important to income.

\section{Past-present-future}

According to this PDM, there are perception changes over time (Figure 14 and Appendix 6). For the past and the present, men put a high number of pebbles on primary swamp and hill forests. They argued that their importance will drop, as these land types might disappear in the next 20 years. In the meantime, secondary forest and "protected" forests gain importance for the future. Men and women placed high scores on current rubber gardens, which seemed to have less importance in the past. Women argued that rubber gardens are crucial, as they can generate income and can be converted to swiddens. According to men, swiddens will lose their central role as food sources, as exploitable soils will be too far away from the village in the future.

\subsection{Traditional medicinal plants and their uses}

During this study 125 medicinal plants (Appendix 8) and 9 other types of remedies (Appendix 7) were recorded. The collection contains plants of 54 botanical families, of which 105 were identified to the species and 19 to the genus level. One plant remains unidentified. Ten plants that were given different names by the traditional healer, turned out to belong to 5 species only.

Medicinal uses for the plants collected were very broad. The plants could treat ailments such as stomach ache, headache, toothache, fever, and insect, snake or centipede bites; some were used in childbirth. The routes of administration and plant parts used varied. For 75 plants the leaves that contain the active ingredient, such as in tea made out of kumis kucing (Orthosiphon aristatus) leaves. The smoke of burned plant parts, for example the root of Ilung asam (Schismatoglottis rupestris) is used as a remedy "to chase Satan" out of the ill person or the house.

Beside the three key informants, only a few people could describe diseases in detail. Ibu Maria distinguished between, for example, three different types of headache. Plants were mostly used in combination; using one alone was rarely seen to be effective. For example, 12 different leaves were used 

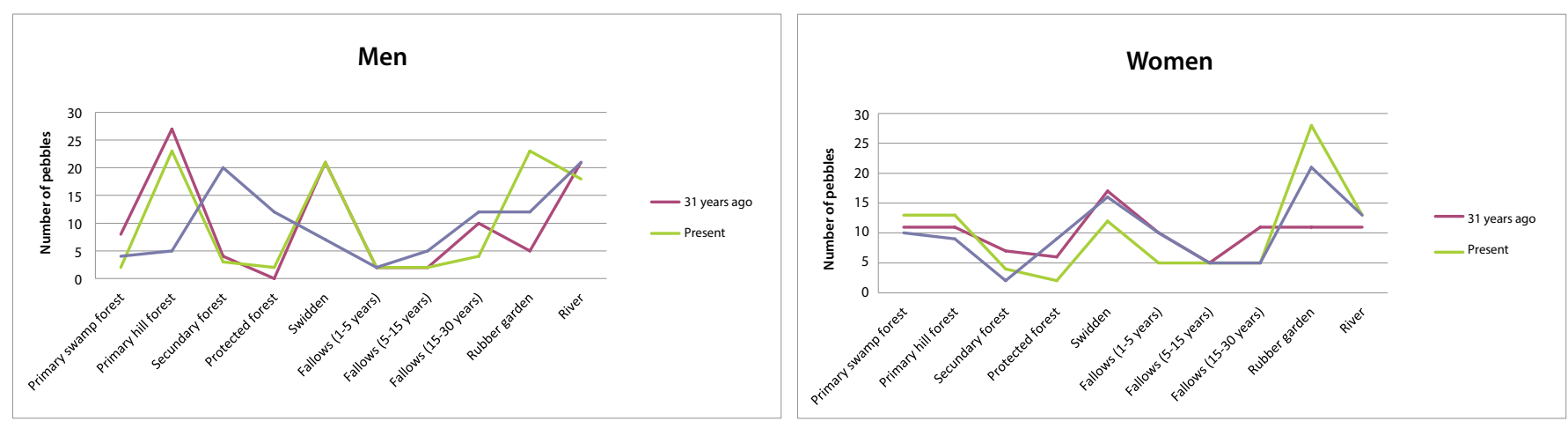

Figure 14. Change of perception in time, past-present-future (men and women groups).

Traditional medicines found in the different landscape units

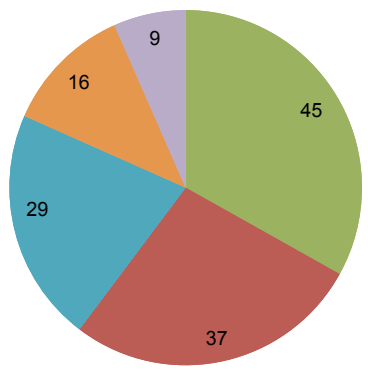

Primary forest

- Village

Swidden

Fallows

River

Figure 15. Proportions of the traditional medicines found in different landscape units.

to treat meniali abdominal pain (when the right side hurts). Some diseases require complex preparations and applications of plant mixtures that are the domain of specialists.

Out of the 136 natural medicines sampled, one third were collected in primary forest (Figure 15). Nearly half were collected in the immediate surroundings of the village and the swiddens. Some were found in the fallows and some on the riverbanks. This is not static data, as plants that are planted in the gardens may also be found in fallows. Furthermore, women grow plants that originate in the primary forest in their gardens or near their homes. Out of the 125 medicinal plants, only 38 were planted and 87 (nearly 70\%) grew naturally in the wild.

\subsection{Ecological analysis}

The quantity and size (dbh) of trees in the different landscape units shows differences for each 0.2 ha plot (Table 3). The highest density of trees, having a dbh over $10 \mathrm{~cm}$, is to be found in the young 5 -year-old fallow (197 trees), followed by the kerangas forest (173 trees), the 15 - year-old fallow (162 trees), the 30 -yearold fallow (147 trees) and the secondary forest (130 trees). The lowest numbers of tree individuals are in the primary hill (103 trees) and swamp forests (99 trees). There is a difference of nearly 100 trees, between the young fallow and the primary swamp forest. Hill, swamp and secondary forests have relatively few small

Table 3. The dbh classes and the total amount of trees per land unit (in each plot of $20 \times 100 \mathrm{~m}$ ).

\begin{tabular}{|c|c|c|c|c|c|c|c|}
\hline \multirow[t]{2}{*}{ Land units } & \multicolumn{6}{|l|}{ Dbh classes } & \multirow{2}{*}{$\begin{array}{l}\text { Total number } \\
\text { of trees } / 0.2 \mathrm{ha}\end{array}$} \\
\hline & {$[10-20 \mathrm{~cm}]$} & {$[20-40 \mathrm{~cm}]$} & {$[40-60 \mathrm{~cm}]$} & {$[60-80 \mathrm{~cm}]$} & {$[80-100 \mathrm{~cm}]$} & {$[100-185 \mathrm{~cm}]$} & \\
\hline 5 year-old fallow & 173 & 24 & & & & & 197 \\
\hline $\begin{array}{l}15 \text { year-old } \\
\text { fallow }\end{array}$ & 99 & 62 & 1 & & & & 162 \\
\hline $\begin{array}{l}30 \text { year-old } \\
\text { fallow }\end{array}$ & 100 & 42 & 5 & & & & 147 \\
\hline secondary forest & 75 & 41 & 10 & 3 & & 1 & 130 \\
\hline kerangas & 107 & 58 & 7 & 1 & & & 173 \\
\hline hill forest & 55 & 31 & 12 & 4 & 1 & & 103 \\
\hline swamp forest & 56 & 33 & 5 & 1 & 1 & 3 & 99 \\
\hline
\end{tabular}


trees (dbh up to $20 \mathrm{~cm}$ ) and the 5-year-old fallow has a large number of small trees. In contrast, big trees of over $60 \mathrm{~cm}$ of dbh are only found in the hill, swamp and secondary forest plots. The fallows and Kerangas have a higher amount of small trees, in larger quantities, whereas the primary hill and swamp forests have a smaller number of trees, but with some very large ones. The swamp forest contained some huge trees of nearly $2 \mathrm{~m}$ in $\mathrm{dbh}$. The secondary forest, which was selectively logged over 30 years ago, has fewer individual trees than the 30-year-old fallow but has some large individual trees.

The kerangas are distinctive land types, which have sandy soils. The superficial roots are very obvious. The poverty of the soil is indicated by the presence of carnivorous plants such as Nepenthes spp. Poor and shallow soils do not allow the trees to grow tall and large, hence there is a high number of small trees in this area.
Table 4. Diversity index $D=1-\lambda$ calculated through the Simpson index $\lambda$

\begin{tabular}{lcc}
\hline Land unit & $\begin{array}{l}\text { Total number of } \\
\text { species }\end{array}$ & $\begin{array}{l}\text { Diversity } \\
\text { index } \\
\mathbf{D}=\mathbf{1}-\boldsymbol{\lambda}\end{array}$ \\
\hline primary swamp forest & 36 & 0.96 \\
\hline primary hill forest & 36 & 0.92 \\
\hline kerangas & 36 & 0.94 \\
\hline secondary forest & 41 & 0.94 \\
\hline fallow 30 years & 31 & 0.77 \\
\hline fallow 15 years & 25 & 0.88 \\
\hline fallow 5 years & 29 & 0.90 \\
\hline
\end{tabular}

The Simpson index (Table 4, Appendix 9) shows that in terms of tree species richness, the swamp

Table 5. The 10 most salient trees and medicinal plants for women and men, according to their frequency (freq.) and their average rank (aver. rank) on the free lists.

\begin{tabular}{|c|c|c|c|c|c|c|c|}
\hline \multicolumn{4}{|c|}{ Women_trees } & \multicolumn{4}{|l|}{ Men_trees } \\
\hline Local name & Smith s & Freq. & Aver. Rank & Local name & Smith s & Freq. & Aver.Rank \\
\hline Nanka & 0.33 & 6 & 7.67 & Benuah & 0.29 & 4 & 5.25 \\
\hline Mangga & 0.28 & 4 & 5.5 & Mangga & 0.28 & 4 & 5.5 \\
\hline Tebedak & 0.28 & 4 & 5.5 & Belian & 0.27 & 5 & 7.8 \\
\hline Pinang & 0.21 & 3 & 5.33 & Durian & 0.27 & 3 & 2.67 \\
\hline Klotok & 0.19 & 2 & 1.5 & Simpat_pinang & 0.25 & 3 & 3.33 \\
\hline Rotan & 0.19 & 2 & 1.5 & Lensat & 0.23 & 3 & 4.33 \\
\hline Rambutan & 0.17 & 2 & 3 & Tomau & 0.21 & 3 & 5.33 \\
\hline Leban & 0.17 & 4 & 9.75 & Lengkeng & 0.19 & 3 & 6.33 \\
\hline Durian & 0.17 & 3 & 7.67 & Empakan & 0.18 & 3 & 7 \\
\hline Tomau & 0.17 & 3 & 7.67 & Embak & 0.17 & 3 & 6.67 \\
\hline \multicolumn{4}{|c|}{ Women_medicinal plants } & \multicolumn{4}{|c|}{ Men_medicinal plants } \\
\hline Local name & Smith s & Freq. & Aver. Rank & Local name & Smith s & Freq. & Aver. Rank \\
\hline Sirih & 0.29 & 5 & 5.4 & Juaran & 0.39 & 4 & 4.00 \\
\hline$J a m b u \_b i j i$ & 0.23 & 3 & 4.33 & Sabang & 0.37 & 3 & 1.33 \\
\hline Kunyit & 0.19 & 3 & 5.33 & Kunyit & 0.35 & 4 & 5.50 \\
\hline Sabang & 0.17 & 2 & 2.5 & Akar_kuning & 0.34 & 4 & 3.75 \\
\hline Juaran & 0.17 & 3 & 7.33 & Entemu & 0.32 & 4 & 5.75 \\
\hline Tabar & 0.16 & 2 & 4 & Tampal & 0.31 & 4 & 4.00 \\
\hline Bungur & 0.15 & 2 & 4.5 & Kumis_kucing & 0.24 & 3 & 5.67 \\
\hline Parap & 0.15 & 2 & 5 & Enke_hidup & 0.16 & 2 & 3.50 \\
\hline Serai & 0.14 & 2 & 4.5 & Tangkai_hidup & 0.15 & 2 & 5.00 \\
\hline Salam & 0.12 & 2 & 5.5 & Belaban_merah & 0.13 & 2 & 8.00 \\
\hline
\end{tabular}


forest is close to the maximum, with $\mathrm{D}=0.96$, followed by the kerangas and logged-over forest (both $\mathrm{D}=0.94$ ). The hill forest has a $\mathrm{D}=0.92$, which is slightly higher than the 5-year-old fallows, where $\mathrm{D}=0.90$. The diversity index drops for older fallows: the 15-year-old fallow has a D of 0.88 and the 30-year-old has the lowest index at $\mathrm{D}=0.77$.

In terms of IVI, the kerangas, swamp and hill forests contain at least three species of the Dipterocarpaceae family, mainly of the genus Shorea, among their dominant species. They are not dominant in human-caused successional forests. The swamp forest can support trees that are dominant due to their huge basal area such as individuals of Koompassia malaccensis or Alstonia angustiloba. The pioneer species Bellucia pentamera, Macaranga hosei and Ficus variegata are dominant in all the fallows.

\subsection{Free lists of trees and medicinal plants}

The indexes of salience, Smith $S$, indicate differences in trees and medicinal plants cited by men and by women (Table 5). Mangga, durian and tomau were among the most prevalent and first mentioned trees for both groups. Three medicinal plants, juaran, sabang and kunyit, seemed to be important to the whole community. Nearly all of the people questioned listed 15 out of the 15 trees $(93 \%$ of answers for the women and $96 \%$ for the men). Half of the named trees were used for their fruits and one third of them were used for house construction. The free lists of medicinal plants were hard to establish for most of the men who were surveyed. While women named $80 \%$ of the plants in the lists, men had shorter lists, with only $60 \%$ of answers. A small number of men displayed an indepth knowledge of medicinal plants, their preparations and routes of administration. 


\section{Discussion}

Overall, the lack of fluency in the local language and in Indonesian by the author was a barrier to the field research, especially at the beginning.

\subsection{Gender-related observations}

Central observations in this study were differences in perceptions between men and women. As observed in other Dayak communities (Gönner 2000; Mulyoutami et al. 2009), some tasks were exclusively the men's or the women's domain, although there was a large amount of common labor. Men were underrepresented in this study, especially during the focus group discussions and the survey of medicinal plants. First, they were mostly away during the 3-month study period and second because for me, as a women, contact with men was time consuming to organize and delicate to establish. Nevertheless, the results of the free lists and the PDM, combined with the villagers' opinions, imply that medicinal plant knowledge is generally more of a women's domain, even if some men had profound knowledge of it. According to Caniago and Siebert (1998), Dayak women in rural Kalimantan usually have deeper knowledge of medicinal plants, as it is they who mostly care for their children's health and manage their gardens.

\subsection{Medicinal plant listing}

Traditional medicine is an integral part of the health system in this area, for financial reasons, because of lack of alternatives and because of its efficiency. The relative isolation of Nanga Dua probably supports the use of medicinal plants and the perpetuation of this knowledge down the generations. The collection of medicinal plants gives us a first insight into this traditional custom. Meanwhile, comparing each sampled plant with bibliographic references, would deepen the analysis of the medicinal plants and the knowledge about them. For example jambu air (Senna alata), which is used to relieve 'itchy skin' has been proven to have antifungal properties according to Sule et al. (2011).

\subsection{Participatory mapping}

For the participatory mapping process, the map lacks accuracy and should be considered as a first draft that provides an overview of the area. The participants were unable to draw boundaries of the different land-use units. Furthermore, only four men and four women participants were present for the mapping procedure, and this does not represent the community as a whole. More GPS data from the field, with active participation of the local population would give a more reliable map (Bujang 2004). Maps are an important tool to empower people who rely on land established through customary institutions and local stakeholders should be included in spatial planning (Kurniawan and Hanafi 2004).

\subsection{The free listing method}

Due to lack of time, not all the trees and medicinal plants named in the free lists were sampled. This analysis is therefore based on local names and not on scientific names. It would have been more valuable from an ethnobotanic perspective to do a more detailed study. Instead of asking the informants to name trees and their uses, it would have been better to make a list for each use category, e.g. one list for tree species used for house construction (Quinlan 2005). Furthermore, as the salience index $S$ takes into account the length of the lists, open listing (not restricted to 15 answers only) would have been more relevant. Moreover, data is generally statistically reliable counting from a minimum of 30 lists per topic (Borgatti and Halgin 1998).

In addition, it was observed that some respondents struggled to do this exercise. Indeed, people generally do not think theoretically about trees and medicinal plants. For instance, one 70-year-old woman could not list 15 medicinal plants while sitting in her house, but when she looked for plants for specific diseases or walks in the surrounding area she knew many plants and was consulted by the villagers because of her knowledge. Field interviews seem in this case to be more appropriate. Hence, the free listings approach is not a deep evaluation of the community's knowledge about tree and medicinal plant uses, but is seen as a first approach. 


\subsection{Ecological analysis}

Vegetation cover in this area is mainly a forest mosaic of different types of vegetation, influenced to different degrees by human activities. In such a mosaic, especially for secondary regrowth, the problem of representativeness of the sampling is an issue (Wagner et al. 2000). A plot sample size of 0.2 ha appears large enough to characterize fallows, but it may not be statistically reliable in large forest areas. For the dipterocarp forests Ashton (1964) used plot sizes of 0.4 ha, but more recent studies sample 1 ha plots (Poulsen et al. 1996; Small et al. 2004). Some authors suggest use of much larger plots (Laumonier et al. 2010) and the CoLUPSIA project is establishing permanent plots of between 2 ha and 6 ha.

Due to lack of time, not all tree leaves were sampled, but only one per local name for each plot. The local classification does not always coincide with scientific classification. This led to a few mistakes, for example trees which had the same local name but different Latin names. For scientific correctness, each single tree should have been sampled.

The secondary forests and young fallows have high tree diversity indexes. The fact that forest disturbance for traditional slash-and-burn agriculture is done on a small-scale and in the immediate vicinity of primary forest, which serves as species reservoir (Mo et al. 2011), enables fast and tree-species-rich forest regeneration.

\subsection{The Kerangas}

The villagers did not include the kerangas as a distinctive land use in their categorization of the landscape, even if they did recognize this type of forest. This is because apart from gaharu gathering and sporadic hunting, the villagers do not use this forest type for agriculture. The kerangas forests are especially sensitive to disturbance, such as clear cutting or fire, as they grow on shallow, dry, sandy soils (Dennis 1999). According to Meijaard et al. (2005) the kerangas forest areas are unable to recover and produce any valuable vegetation after the trees have been cut. The villagers are aware of that, as they categorized this type of vegetation as forest that is protected from cutting through customary law. One other reason is that there were mostly women present during the focus group discussions about land uses. Women do not look for gaharu or hunt, so it might not seem an important land-use feature to them as they rarely enter the kerangas.

\subsection{The role of vulnerable forestry resources}

During my stay in the village and through the participatory surveys it became evident that the inhabitants of Nanga Dua Village use a broad variety of forest products on a daily basis. Rubber tree tapping is likely to become a more important resource in the future, once the trees are old enough. Local people seemed to be aware of the vulnerability of their forestry resources. The scoring exercises showed that primary forest was seen by local people as at risk of disappearing in the future and represents an important source of resources, such as food, handicrafts, and house and boat construction material. Primary swamp and hill forest play a crucial role as sources of income. As local people use medicinal plants to treat common ailments and illnesses, degradation of the forest may imply a loss of their healthcare options (Shanley and Luz 2003). This research highlights that the majority of medicinal plants originate from the primary forest, either through direct extraction or through selected planting of species gathered there. The fact that villagers observe that wild animals are becoming scarcer raises more questions. Wild animal resource management is not sustainable. A broad spectrum of species are hunted locally, some of which have lower populations and are protected by national law, such as the sun bear (Helarctos malayanus), which is classed as vulnerable on the IUCN Red List (Fredriksson et al. 2008) or the Sunda pangolin (Manis javanica), which is classed as endangered (Duckworth et al. 2008). It is important to study in detail these aspects of sustainable natural resource management and support the local community in order to ensure the lasting presence of wildlife. The scarcity of wildlife may be connected to the absence of fruit during the survey period. A stay of 3 months is not long enough to fully understand people's resource management issues, especially as it depends on seasonal rain variations. 


\section{Conclusion}

This study brings new insights on a Dayak Mentebah community and the ways they perceive and use their environment.

The communities of Nanga Dua and neighboring villages are dependent on forestry resources. Despite the economic incomes earned through gold mining along rivers, people still rely on hunting and gathering; and on the fruits, vegetables and rice from their swiddens. Forest products are widely used for basketry, construction of houses or boats, fuelwood and food. The participatory surveys show that primary swamp and hill forest are important reservoirs of resources and that the people of Nanga Dua rely on them and know how to use them.

The traditional, consecutive land clearing for shifting cultivation in this area causes the formation of vegetation patches with different succession stages. These human-modified areas, which are mixtures of secondary regrowth and gardens are very rich biologically. Exploitation is on a smallscale and the swidden agriculture is embedded into the surrounding primary forest landscape, which explains the high diversity of tree species in the different land-use types. The secondary forest and young fallows have an important conservation value. Hill kerangas forests, where sporadic hunting and gaharu gathering is practiced, are protected from timber extraction by traditional law.

Traditional medicine remains an integral part of the health system in the area. Local people have remarkable knowledge of species and their uses as remedies. The relatively isolated location of the village probably sustains the traditional lifestyle. Meanwhile, socioeconomic, traditional and ecological settings are changing fast. People hope that the old logging road will be restored, which would give better access to the district's road network. Through this, access to better healthcare options and to other economic activities would become possible.

However, the opinions and needs of local people should be considered for any development project on their land. The rights to own and decide upon their ancestral lands have to be respected, in order to protect the rich cultural and natural heritage of the region. 


\section{References}

Ahlenius H. 2007. Extent of deforestation in Borneo 1950-2005 and projection towards 2020. UNEP/GRID-Arendal Maps and Graphics Library. http://www.grida.no/ graphicslib/ detail/extent-of-deforestation-inborneo-1950-2005-and-projection-towards2020_119c

Appanah S and Turnbull JW. 1998. A Review of Dipterocarps: Taxonomy, Ecology and Silviculture. Bogor, Indonesia: CIFOR. URL: http:// www.cifor.org/publications/pdf_files/Books/ Dipterocarps.pdf

Ashton PS. 1964. Ecological studies in the mixed dipterocarp forests of Brunei State. Oxford Forestry Memoirs 25:1-75.

Ashton PS. 1982. Dipterocarpaceae. In van Steenis CGGJ. Flora Malesiana, Series I, Vol. 9, pp. 237-552.

Balée W. 2010. Contigent diversity on anthropic landscapes. Diversity 2:163-81. URL: www. mdpi.com/1424-2818/2/2/163/pdf

Borgatti SP. 1992. ANTHROPAC 4.98, Analytic technologies, Colombia. http://www. analytictech.com/anthropac/anthropac.htm

Borgatti SP and Halgin DS. 1998. Elicitation techniques for cultural domain analysis. In Schensul J and Weeks M, eds The Ethnographer's Toolkit, Vol. 3. http://www.steveborgatti.com/ papers/bhetk.pdf

BPS-Statistics. 2010. Kalimantan Barat in Figures 2010, Badan pusat statistik - Provinsi Kalimantan Barat, Percetakan. kalbarprov.go.id/statistik/2010/ FILE/KDA2010.pdf

Bujang M. 2004. Malaysia's case study. A community initiative: mapping Dayak's customary lands in Sarawak. Borneo Resources Institute (BRIMAS). Regional community Mapping Network. www.iapad.org/publications/ppgis/brimas_ malaysia.pdf

Caniago I and Siebert SF. 1998. Medicinal plant ecology, knowledge and conservation in Kalimantan, Indonesia. Economic Botany 52(3):229-50.

Carol J, Colfer P, Brocklesby MA, Diaw C, Etuge P, Günter M, Harwell E, McDougall C, Porro NM, Porro R et al. 1999. The Grab Bag: Supplementary Methods for Assessing Human Wellbeing. The Criteria and Indicators Toolbox Series
No. 6. Bogor, Indonesia: CIFOR. http://www. cifor.org/livesinforests/publications/pdf_files/ toolbox-6c.pdf

Chambers R. 1994, Participatory rural appraisal (PRA): Challenges, potentials and paradigms. World Development 22(10):1437-54. https:// entwicklungspolitik.uni-hohenheim.de/uploads/ media/Day_4_-_Reading_text_7_02.pdf

[CIFOR] Center for International Forestry Research. 2012. CIFOR and Indonesia: A Partnership for Forests and People. Bogor, Indonesia: CIFOR. www.cifor.org/publications/pdf_files/Books/ BCIFOR1201.pdf

[CIRAD] Centre de coopération Internationale en Recherche Agronomique pour le Développement. 2010. Collaborative Land Use Planning and Sustainable Institutional Arrangements for Strengthening Land Tenure, Forest and Community Rights in Indonesia. CoLUPSIA, Centre de coopération Internationale en Recherche Agronomique pour le Développement (CIRAD). http://ur-bsef. cirad.fr/en/main-projects/colupsia

Comptour M. 2011. Exploring trees diversity and local perceptions in primary forest and other human land uses in West Kalimantan, Indonesia. Internship Report M2 IEGB, CIFOR and CIRAD.

Contreras-Hermosilla A and Fay C. 2005. Strengthening forest management in Indonesia through land tenure reform: Issues and framework for action. Forest Trends and World Agroforestry Centre. www.forest-trends.org/documents/files/ doc_107.pdf

Corbett J. 2009. Good practices in participatory mapping: A review prepared for the International Fund for Agricultural Development (IFAD). Rome: IFAD. www.ifad. org/pub/map/pm_web.pdf

Crevello S. 2004. Dayak land-use systems and indigenous knowledge. Journal of Human Ecology 16(2)69-73. http://www.krepublishers.com/02Journals/JHE/JHE-16-0-000-000-2004-Web/ JHE-16-1-001-073-2004-Abst-PDF/JHE-16-1069-073-2004-Crevello-S/JHE-16-1-069-0732004-Crevello-S.pdf

Crevello S. 2003. Local land use on Borneo: Applications of indigenous knowledge systems and natural resource utilization among the Benuaq Dayak of 
Kalimantan, Indonesia. Louisiana State University and Agricultural and Mechanical College.

Curran LM, Trigg SN, McDonald K, Astiani D, Hardiono YM, Siregar P, Caniago I and Kasischke E. 2004. Lowland forest loss in protected areas of Indonesian Borneo. Science 303(5660):1000-03. http://www.sciencemag. org/content/303/5660/1000

Curtis JT and Cottam G. 1962. Plant Ecology Workbook: Laboratory Field and Reference Manual. Minneapolis: Burgess Publishing.

Dennis R. 1999. A review of fire projects in Indonesia (1982-1998). Bogor, Indonesia: CIFOR. www.cifor.org/fire/pdf/pdf20.pdf

Duckworth JW, Pattanavibool A, Newton P and van Nhuan N. 2008. Manis javanica. IUCN Red List of Threatened Species, Version 1. URL: http://www.iucnredlist.org/ details/12763/0

[FAO] Food and Agriculture Organization of the United Nations. 2011. State of the world's forests. Rome: FAO. URL: http://www.fao.org/ docrep/013/i2000e/i2000e.pdf

[FAO] Food and Agriculture Organization of the United Nations. 2010. Global forest resources assessment 2010: Main report. FAO Forestry Paper No. 163. Rome: FAO. URL: http://www. fao.org/docrep/013/i1757e/i1757e.pdf

Fontanel J and Chantefort A. 1978. Bioclimats du monde indonésien. Bioclimates of the Indonesian Archipelago. Pondicherry, India: Institut Francais de Pondichery.

Fredriksson G, Steinmetz R, Wong S and Garshelis DL. 2008. Helarctos malayanus. IUCN Red List of Threatened Species, Version 1. http://www. iucnredlist.org/details/9760/0

Fuller DO, Jessup TC and Salim A. 2004. Loss of forest cover in Kalimantan, Indonesia, since the 1997-1998 El Nino. Conservation Biology 18(1):249-54.

Galdikas BM. 2009. Climate, forest ecology and orangutans. Orangutan Foundation International. http://www.orangutan.org/ archives $/ 550$

Gerique A. 2006. An introduction to ethnoecology and ethnobotany: Theory and methods. Department of Geography, University of Giessen. www. utpl.edu.ec/summerschool/images/stories/ presentaciones/ethnoecology.pdf

Global Forest Watch. 1995. Indonesia's forests in brief. http://www.globalforestwatch.org/english/ indonesia/forests.htm
Gönner C. 2002. A Forest Tribe of Borneo. Man and Forest Series 3. New Delhi: DK Printworld.

Gönner C. 2000. Resource management in a Dayak Benuaq village. Strategies, dynamics and prospects: A case study from East Kalimantan, Indonesia. Deutsche Gesellschaft für Technische Zusammenarbeit (GIZ, former GTZ), Eschborn, 126 pp.

Hédl R, Svátek M, Dancak M, Rodzay AW, Salleh $M$ and Kamariah AS. 2009. A new technique for inventory of permanent plots in tropical forests: A case study from lowland dipterocarp forest in Kuala Belalong, Brunei Darussalam. Blumea 54:124-130. http://old.botany.upol.cz/ prezentace/dancak/inventory_plots_tropical_ forests.pdf

Hill R. 2008. Linking cultural and natural diversity of global significance to vibrant economies. In Stork N and Turton SM, eds. Living in a Dynamic Tropical Forest Landscape. Australia: Blackwell Publishing.

Istiyani CP. 2008. Memahami peta keberagaman subsuku dan bahasa dayak di kalimantan barat. Institut Dayakologi, 31 pp.

Jessup T and Vayda AP. 1988. Dayaks and forests of the interior of Borneo. Expedition 30(1): 5-17. www.penn.museum/documents/publications/ expedition/ PDFs/30-1/Jessup.pdf

Joshi L, Wijaya K, Sirait M and Mulyoutami E. 2004. Indigenous systems and ecological knowledge among Dayak people in Kutai Barat, East Kalimantan: A preliminary report. ICRAF Southeast Asia Working Paper no. 3, 22 pp. http://www.worldagroforestry.org/downloads/ publications/PDFs/wp04193.pdf

Katagiri S, Yamakura T and Lee SH. 1991. Properties of soils in kerangas forest on sandstone at Bako National Park, Sarawak, East Malaysia. Southeast Asian Studies 29(1):35-48.

Kitzinger J. 1994. The methodology of focus groups: The importance of interaction between research participants. Sociology of Health and

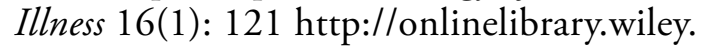
com/doi/10.1111/1467-9566.ep11347023/pdf

Kleinman PJA, Pimentel D and Bryant RB. 1995. The ecological sustainability of slash-andburn agriculture. Agriculture, Ecosystems and Environment 52:235-49.

Kurniawan I. and Hanafi I. 2004. Community mapping, natural resources and indigenous people movement in Indonesia. Jaringan Kerja Pemetaan Partisipatif (JKPP), Indonesian Community 
Mapping Network. www.iapad.org/publications/ ppgis/jkpp_ino.pdf

Laumonier Y. 1997. The Vegetation and Physiography of Sumatra. Utrecht, the Netherlands: Kluwer Academic Publishers.

Laumonier Y, Edin A, Kanninen M and Munandar AW. 2010. Landscape-scale variation in the structure and biomass of the hill dipterocarp forest of Sumatra: Implications for carbon stock assessments. Forest Ecology and Management 259(3):505-13.

Lynam T. 1999. Adaptive analysis of locally complex systems in a globally complex world. Conservation Ecology 3(2): 13. http://www. ecologyandsociety.org /vol3/iss2/art13/

Martin GJ. 2004. Ethnobotany: A Methods Manual. London: Earthscan, 268 pp.

Meijaard E, Sheil D, Nasi R, Augeri D, Rosenbaum B, Iskandar D, Setyawati T, Lammertink M, Rachmatika I, Wong A. et al. 2005. Life after Logging: Reconciling Wildlife Conservation and Production forestry in Indonesian Borneo. CIFOR and UNESCO, 345 pp. www. cifor.org/publications/pdf_files/books/ BMeijaard0501E0.pdf

Michon G, Aulong S, Bérenger E, Clément I, Goloubinoff M, Katz E and Sellato B. 2005. Domesticating forests: How farmers manage forest resources. Bogor, Indonesia: CIFOR, 187 pp. www.cifor.org/publications/pdf_files/ Books/BMichon0501E1.pdf

Millennium Ecosystem Assessment. 2005. Ecosystems and Human Well-being: Synthesis Report. Island Press.

Miettinen J, Shi C and Liew SC. 2011. Deforestation rates in insular Southeast Asia between 2000 and 2010. Global Change Biology 17:2261-70.

Mo XX, Zhu H, Zhang YJ, Slik FJW and Liu JX. 2011. Traditional forest management has limited impact on plant diversity and composition in a tropical seasonal rainforest in SW China. Biological Conservation 144:183240. www.phylodiversity.net/fslik/index_files/ BiolCon2011.pdf

Mulyoutami E, Rismawan R and Joshi L. 2009. Local knowledge and management of simpukng (forest gardens) among the Dayak people in East Kalimantan, Indonesia. Forest Ecology and Management 257:2054-61.

Myers N, Mittermeier RA, Mittermeier CG, Da Fonseca GAB, Kent J. 2000. Biodiversity hotspots for conservation priorities, Nature, vol. 403, pages
853-858. http://www.nature.com/nature/journal/ v403/n6772/full/403853a0.html

Oldeman L, Irsal R and Muladi L. 1980. Agroclimatic map of Kalimantan. Central Research Institute for Agriculture, Bogor. http://eusoils. jrc.ec.europa.eu/esdb_archive/eudasm/asia/maps/ ID2000_4CL.htm

Palm C, Sanchez P, Ahamed S and Awiti A. 2007. Soils: A contemporary perspective. Annual Review of Environment and Resources 32:99-129.

Persoon GA and Osseweijer M. 2008. Reflections on the Heart of Borneo. Wageningen, the Netherlands: Tropenbos International.

Pieroni A, Price L and Vandebroek I. 2005. Welcome to journal of ethnobiology and ethnomedicine. Journal of Ethnobiology and Ethnomedicine 1(1). http://www.ethnobiomed. $\mathrm{com} /$ content $/ 1 / 1 / 1$

Poffenberger M and McGean B. 1993. Communities and forest management in East Kalimantan: Pathway to environmental stability. Southeast Asia Sustainable Forest Management Network, 65 pp. pdf.usaid.gov/pdf_docs/PNABR679.pdf

Poulsen AD. Neilsen IC, Tan S and Balslev H. 1996. A quantitative inventory of trees in one hectare of mixed dipterocarp forest in Temburong, Brunei Darussalam. In Edwards DS, Booth WE and Choy S, eds. Tropical Rainforest Research: Current Issues. The Netherlands: Kluwer Academic Publishers, pp 139-50.

Quinlan M. 2005. Considerations for collecting freelists in the field: Examples from ethobotany. Field Methods17(3). http://libarts. wsu.edu/anthro/pdf/Considerations $\% 20$ for $\% 20$ Collecting.pdf

Sagar R and Sharma GP. 2012. Measurement of alpha diversity using Simpson index $(1 / \lambda)$ : The jeopardy. Environmental Skeptics and Critics 1(1):23-24. http://www. iaees.org/publications/ journals/environsc/articles/2012-1(1)/ measurement-of-alpha-diversity-using-Simpsonindex.pdf

Setyawan AD. 2010. Biodiversity conservation strategy in a native perspective: case study of shifting cultivation at the Dayaks of Kalimantan. Nusantara Bioscience 2(2):97-108. http://biosains.mipa.uns. ac.id/wp-content/uploads/2011/02/ N020208AHMDayakSwiddenx+ENG+.pdf

Shanley P and Luz L. 2003. The impacts of forest degradation on medicinal plant use and implications for health care in Eastern 
Amazonia. BioScience 53(6):573-84. http:// www.cifor.org/publications/pdf_files/research/ forests_health/22.pdf

Sheil D, Puri RK, Basuki I, van Heist M, Wan M, Liswanti N, Rukmiyati, Sardjono MA, Samsoedin I, Sidiyasa K. et al. 2003. Exploring Biological Diversity, Environment and Local People's Perspectives in Forest Landscapes: Methods for a Multidisciplinary Landscape Assessment. Bogor, Indonesia: CIFOR. www. cifor.org/mla/download/publication/exploring_ bio.pdf

Simpson EH. 1949. Measurement of diversity. Nature 163: 688.

Small A, Martin TG, Kitching RL and Wong KM. 2004. Contribution of tree species to the biodiversity of a 1 ha Old World rainforest in Brunei, Borneo. Biodiversity and Conservation 13:2067-88.

Sobrevila C. 2008. The role of indigenous peoples in biodiversity conservation-the natural but often forgotten partners. World Bank, Washington, DC. siteresources.worldbank. org/INTBIODIVERSITY/Resources/Roleof IndigenousPeoplesinBiodiversityConservation.pdf Subehan S, Ueda J, Fujino H, Attamimi F and Kadota S. 2005. A field survey of agarwood in Indonesia. Journal of Traditional Medicines 22(4):244-51. http://utomir.lib.u-toyama. ac.jp/dspace/bitstream/10110/1236/1/ JTrMed22244.pdf
Sule WF, Okonko IO, Omo-Ogun S, Nwanze JC, Ojezele MO, Ojezele OJ, Alli JA, Soyemi ET and Olaonipekun TO. 2011. Phytochemical properties and in-vitro antifungal activity of Senna alata Linn. crude stem bark extract. Journal of Medicinal Plants Research 5(2):176-83. www.academicjournals.org/ jmpr/PDF/pdf2011/18Jan/Sule\%20et\%20al.pdf

Symington CF. 1943. Foresters' manual of dipterocarps. Malaysian Forest Records no.16. Penerbit Universiti Malaya, Kuala Lumpur, Malaysia.

The Plant List. 2010. The Plant List: A Working List of All Plant Species. Version 1. http://www. theplantlist.org/

van Steenis CGGJ. 1972. The Mountain Flora of Java. Leiden, the Netherlands: Brill.

Wagner H, Wildi O and Ewald KC. 2000. Additive partitioning of plant species diversity in an agricultural mosaic landscape. Landscape Ecology 15:219-27. www.utm.utoronto.ca/ - wagnerh 1/ PDFs/Wagner_etal_LandEcol_2000.pdf

Whitmore TC. 1988. Tropical Rain Forests of the Far East, 2nd ed. Oxford: Oxford University Press.

Whittaker RJ, Willis KJ and Field R. 2001. Scale and species richness: Towards a general, hierarchical theory of species diversity. Journal of Biogeography 28(4):453-70.

World Bank. 2010. Data: Forest area (sq. km). http://data.worldbank.org/indicator/AG.LND. FRST.K2?order=wbapi_data_value_2010\%20 wbapi_data_value $\% 20$ wbapi_data_valuefirst\&sort=asc\&display=default 


\section{Appendices}

Appendix 1. Two data sheet examples for the 60 free lists of species of medicinal plants and trees

\section{Medicinal plants:}

\begin{tabular}{lllll}
\hline Gender/age informant: Bapak Simon (50 years) & & & \\
\hline Local name & Use & Plant part & Procedure & Location \\
\hline Pasak bumi & Fever & Leave & Drink tea & Forest/fallows \\
\hline Akar kuning & Fever & Leave & Drink tea & Forest/fallows \\
\hline Kayu semulang & Defecate blood, abdominal pain & Leave & Drink tea & Fallows \\
\hline Kulit senkuang & Stomach ache & Leave & Drink tea & River \\
\hline Rumput langau & Period too long & Leave & Rub on body & Village \\
\hline Kenjin jawa & Abdominal pain & Fruit & Cook and eat & Forest \\
\hline Rumput pelir kambing & Fever, stomach ache & Leave & Compress & Forest/fallows \\
\hline Patampal & Itchy wound & Leave & Compress & Swidden \\
\hline Jenung & Centipede bite & Leave & Compress & Swidden \\
\hline Parapapi & Fever & Root & Drink tea & Fallows \\
\hline Rumput badi kalui & Stomach ache & Leave & Compress & Swidden \\
\hline Rumput sumpit hantu & Body ache & Leave & Compress & Forest \\
\hline Rumput belanda & Wound & Leave & Compress & Village \\
\hline Jambu air & Stomach ache & Leave & Drink tea & River \\
\hline Bengkal & Fever, stomach ache & Leave & Drink tea & River \\
\hline & & & & \\
\hline
\end{tabular}

Trees:

\begin{tabular}{lll}
\hline Gender/age informant: Ibu Maria (48 years) & \\
\hline Local name & Use & Location \\
\hline Belian & House, boat construction & Forest \\
\hline Benuah & House construction & Forest \\
\hline Simpak pinang & House construction & Forest \\
\hline Pelaik & House construction & Forest \\
\hline Durian & Fruit & Forest/Swidden \\
\hline Tenkawang & Fruit & Forest \\
\hline Sikup & Fruit & Fallows \\
\hline Kempas & House construction & Forest \\
\hline Bedaru & House construction & Forest \\
\hline Linang & Fruit & Forest \\
\hline Tapang & Honeybee tree & Forest \\
\hline Kemarawang & House construction & Forest \\
\hline Kayugaru & Oil & Forest \\
Damar & Sap & Forest \\
\hline
\end{tabular}




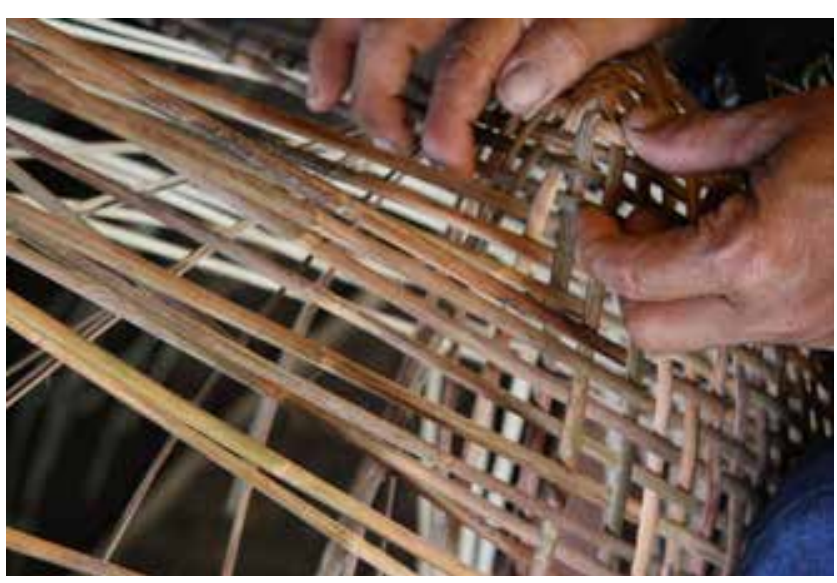

Ibu Tuman making a basket used for fishing

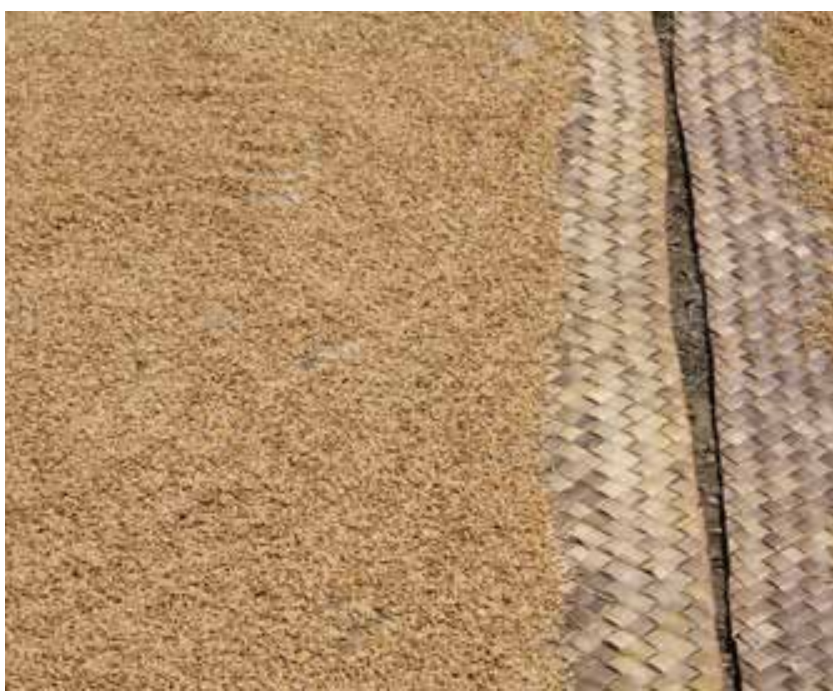

Mats used for drying rice in the sun

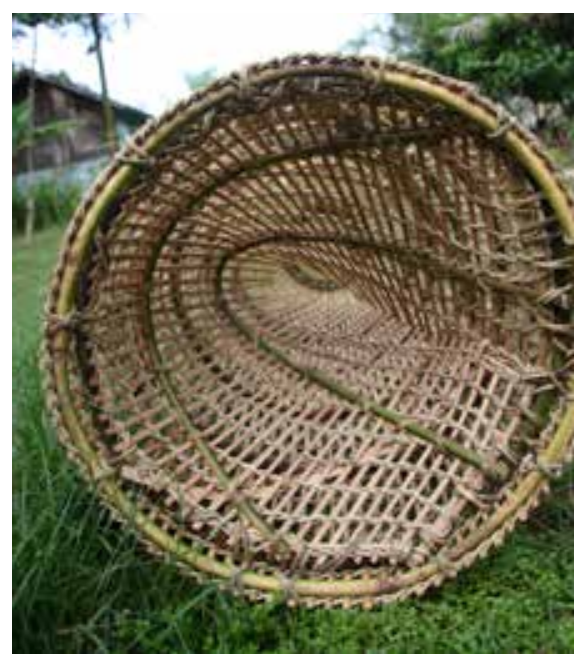

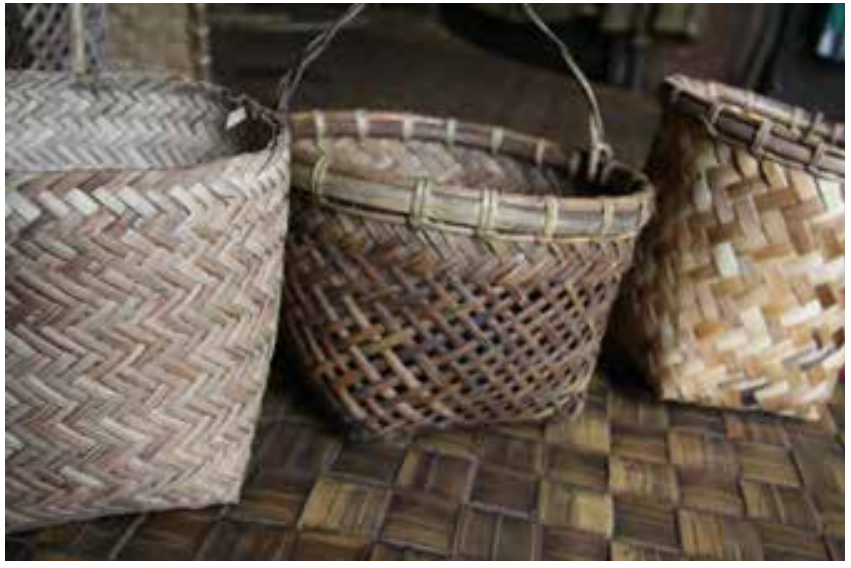

Different types of baskets

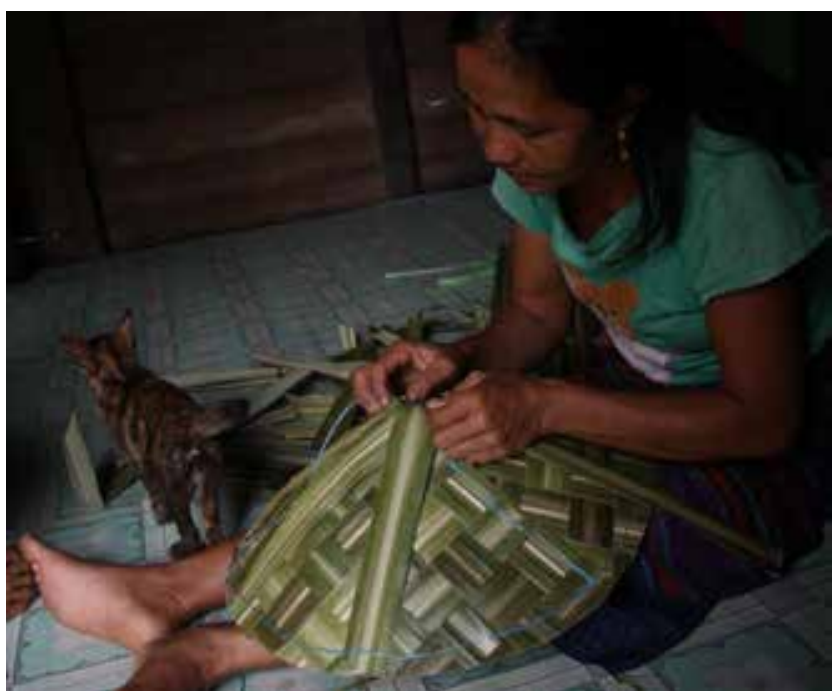

Ibu Sodak creates a hat, named Tangui, using peropok and rattant

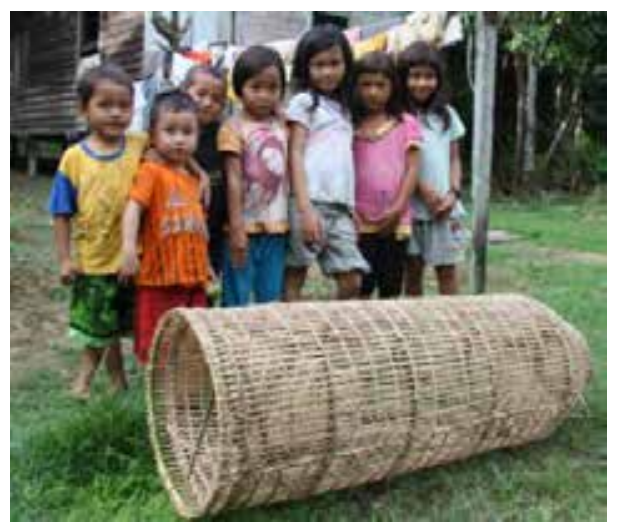

A fish trap made out of rattan 
Appendix 3. Important species for each use category

\begin{tabular}{|c|c|c|}
\hline \multirow{2}{*}{$\begin{array}{l}\text { Use } \\
\text { category }\end{array}$} & \multicolumn{2}{|c|}{ Important species } \\
\hline & Local name & Location \\
\hline \multirow{29}{*}{$\begin{array}{l}\text { Hunting } \\
\text { Berburu }\end{array}$} & Babi hutan & Primary forest \\
\hline & Rusa & Primary forest \\
\hline & Kidjang & Primary forest \\
\hline & Kancil & Primary forest \\
\hline & Munsang & Primary forest \\
\hline & Biawa & Primary forest \\
\hline & Beruang & Primary forest \\
\hline & Monyet kopuhan & Primary forest \\
\hline & Monyet kopo & Primary forest \\
\hline & Monyet kelasi & Primary forest \\
\hline & Monyet kera & Primary forest \\
\hline & Monyet empiau & Primary forest \\
\hline & Getang prahu & Primary forest \\
\hline & Mpisi & Primary forest \\
\hline & Landak & Primary forest \\
\hline & Lanki & Primary forest \\
\hline & Berumtok & Primary forest \\
\hline & Memar & Primary forest \\
\hline & Enkuli & Primary forest \\
\hline & Kubong & Primary forest \\
\hline & Ribu & Primary forest \\
\hline & Tengilin & Primary forest \\
\hline & Poncin & Primary forest \\
\hline & Tupai & Primary forest \\
\hline & Burung tingan & Primary forest \\
\hline & Burung tajak & Primary forest \\
\hline & Burung totoh & Primary forest \\
\hline & Burung kuko & Primary forest \\
\hline & Didit & Primary forest \\
\hline \multirow{8}{*}{$\begin{array}{l}\text { Basketry } \\
\text { Anyaman }\end{array}$} & Perupuk & Fallows \\
\hline & Rassau & Primary forest \\
\hline & Kaseipu & Primary forest \\
\hline & Rottan & Primary forest \\
\hline & Enkodjak & Primary forest \\
\hline & Sengang & Fallows \\
\hline & Mujan & Primary forest \\
\hline & Bamboo & Swidden \\
\hline
\end{tabular}

\begin{tabular}{|c|c|c|}
\hline \multirow{2}{*}{$\begin{array}{l}\text { Use } \\
\text { category }\end{array}$} & \multicolumn{2}{|l|}{ Important species } \\
\hline & Local name & Location \\
\hline \multirow{19}{*}{$\begin{array}{l}\text { Food } \\
\text { Makanan }\end{array}$} & Tebu & Swidden \\
\hline & Padi & Swidden \\
\hline & Ubi jalar & Swidden \\
\hline & Jagung & Swidden \\
\hline & Ubi Rambat & Swidden \\
\hline & Singkong (Ubi kayu) & Swidden \\
\hline & Terong & Swidden \\
\hline & Keladi & Swidden \\
\hline & Mentimon & Swidden \\
\hline & Cabe & Swidden \\
\hline & Sawi & Swidden \\
\hline & Gambas & Swidden \\
\hline & Punjat & Swidden \\
\hline & Jahe & Swidden \\
\hline & Labu & Swidden \\
\hline & Perengi & Swidden \\
\hline & Durian & Swidden \\
\hline & Pisang & Swidden \\
\hline & Mangga & Swidden \\
\hline \multirow{17}{*}{$\begin{array}{l}\text { Medicinal } \\
\text { plants } \\
\text { Tanaman } \\
\text { obat }\end{array}$} & Sandu & Primary forest \\
\hline & Lukai & Primary forest \\
\hline & Muar & Primary forest \\
\hline & Pata issao & Primary forest \\
\hline & Senkai & Primary forest \\
\hline & Onang-onang & Primary forest \\
\hline & Sedeniakar & Primary forest \\
\hline & Parapapi & Primary forest \\
\hline & Akar kuning & Primary forest \\
\hline & llung & Primary forest \\
\hline & Situ utcin & Primary forest \\
\hline & Akar perlulu & Primary forest \\
\hline & Empilak merah & Primary forest \\
\hline & Akar lakup & Fallows \\
\hline & Tengedak merah & Primary forest \\
\hline & Kayu mancut & Fallows \\
\hline & Jenis rumput & Fallows \\
\hline
\end{tabular}

\begin{tabular}{|c|c|c|}
\hline \multirow{2}{*}{$\begin{array}{l}\text { Use } \\
\text { category }\end{array}$} & \multicolumn{2}{|l|}{ Important species } \\
\hline & Local name & Location \\
\hline \multirow{12}{*}{$\begin{array}{l}\text { Fire wood } \\
\text { Kayu bakar }\end{array}$} & Lebatn & Fallows \\
\hline & Mehinai & Fallows \\
\hline & Mandin & Fallows \\
\hline & Itap & Fallows \\
\hline & Timau & Fallows \\
\hline & Pelampai & Fallows \\
\hline & Enkunit & Primary forest \\
\hline & Kerecis & Primary forest \\
\hline & Kumpang & Primary forest \\
\hline & Ponjang & Primary forest \\
\hline & Habai & Primary forest \\
\hline & Tekujong & Primary forest \\
\hline \multirow{4}{*}{$\begin{array}{l}\text { Fodder } \\
\text { Makanan } \\
\text { ternak }\end{array}$} & Selinkat & Fallows \\
\hline & Padi & Swidden \\
\hline & Jagung & Swidden \\
\hline & Singkong & Swidden \\
\hline \multirow{10}{*}{$\begin{array}{l}\text { Marketable } \\
\text { products } \\
\text { Produk untuk } \\
\text { dijual }\end{array}$} & Gaharu & Primary forest \\
\hline & Gaharu ranci & Primary forest \\
\hline & Gaharu buaya & Primary forest \\
\hline & Gaharu Ntamban & Primary forest \\
\hline & Kayu badaru & Primary forest \\
\hline & Kayu menuah & Primary forest \\
\hline & Kayu Belian & Primary forest \\
\hline & Kayu tenkawang & Primary forest \\
\hline & Kayu menhirai & Primary forest \\
\hline & Kayu buabuahan & Primary forest \\
\hline \multirow{6}{*}{$\begin{array}{l}\text { Ornaments } \\
\text { Hiasan, adat }\end{array}$} & Bamboo & Swidden \\
\hline & Rottan & Primary forest \\
\hline & Daun samir & Primary forest \\
\hline & Daun kelapa & Primary forest \\
\hline & Daun pinang & Primary forest \\
\hline & Rassau & Primary forest \\
\hline \multirow{5}{*}{$\begin{array}{l}\text { Construction } \\
\text { Konstruksi }\end{array}$} & Tekam & Primary forest \\
\hline & Belian & Primary forest \\
\hline & Meranti & Primary forest \\
\hline & Tomau & Primary forest \\
\hline & Menuah & Primary forest \\
\hline
\end{tabular}


Appendix 4. Data sheet for the pdm: Importance of each land unit for the use categories

\begin{tabular}{|c|c|c|c|c|c|c|c|c|c|c|c|c|c|c|c|}
\hline MEN & 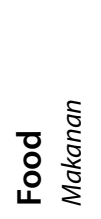 & 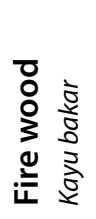 & 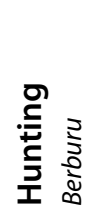 & 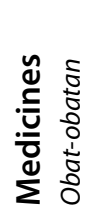 & 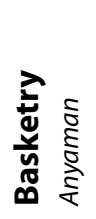 & 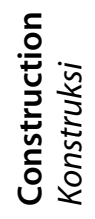 & 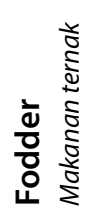 & WOMEN & 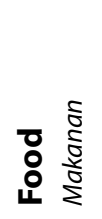 & 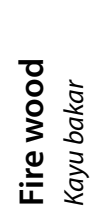 & 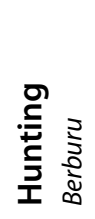 & 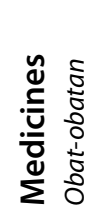 & 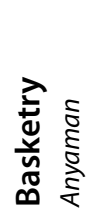 & 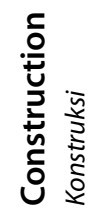 & 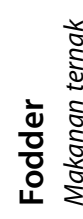 \\
\hline $\begin{array}{l}\text { Primary } \\
\text { swamp } \\
\text { forest } \\
\text { Hutan rimba } \\
\text { rawa }\end{array}$ & 0 & 5 & 13 & 0 & 20 & 5 & 0 & $\begin{array}{l}\text { Primary } \\
\text { swamp } \\
\text { forest } \\
\text { Hutan rimba } \\
\text { rawa }\end{array}$ & 6 & 11 & 11 & 11 & 5 & 20 & 0 \\
\hline $\begin{array}{l}\text { Primary hill } \\
\text { forest } \\
\text { Hutan rimba } \\
\text { gunung }\end{array}$ & 14 & 20 & 32 & 37 & 37 & 52 & 0 & $\begin{array}{l}\text { Primary hill } \\
\text { forest } \\
\text { Hutan rimba } \\
\text { gunung }\end{array}$ & 7 & 8 & 16 & 20 & 25 & 33 & 0 \\
\hline $\begin{array}{l}\text { Secundary } \\
\text { forest } \\
\text { Hutan babas }\end{array}$ & 7 & 43 & 0 & 25 & 0 & 0 & 28 & $\begin{array}{l}\text { Secundary } \\
\text { forest } \\
\text { Hutan babas }\end{array}$ & 6 & 13 & 16 & 6 & 12 & 16 & 0 \\
\hline $\begin{array}{l}\text { Protected } \\
\text { forest } \\
\text { Hutan adat }\end{array}$ & 0 & 0 & 2 & 0 & 0 & 0 & 0 & $\begin{array}{l}\text { Protected } \\
\text { forest } \\
\text { Hutan adat }\end{array}$ & 0 & 0 & 0 & 9 & 0 & 0 & 0 \\
\hline $\begin{array}{l}\text { Swidden } \\
\text { Ladang }\end{array}$ & 49 & 0 & 0 & 0 & 0 & 0 & 46 & $\begin{array}{l}\text { Swidden } \\
\text { Ladang }\end{array}$ & 26 & 9 & 0 & 11 & 0 & 0 & 42 \\
\hline $\begin{array}{l}\text { Fallows (1-5 } \\
\text { years) } \\
\text { Bekas ladang }\end{array}$ & 11 & 2 & 2 & 11 & 0 & 0 & 11 & $\begin{array}{l}\text { Fallows (1-5 } \\
\text { years) } \\
\text { Bekas ladang }\end{array}$ & 7 & 13 & 9 & 7 & 9 & 0 & 21 \\
\hline $\begin{array}{l}\text { Fallows } \\
\text { (5-15 years) } \\
\text { Bekas ladang }\end{array}$ & 0 & 15 & 15 & 8 & 15 & 15 & 15 & $\begin{array}{l}\text { Fallows } \\
\text { (5-15 years) } \\
\text { Bekas ladang }\end{array}$ & 6 & 18 & 15 & 10 & 23 & 20 & 21 \\
\hline $\begin{array}{l}\text { Fallows } \\
(15-30 \\
\text { years) } \\
\text { Bekas ladang }\end{array}$ & 4 & 5 & 23 & 4 & 28 & 28 & 0 & $\begin{array}{l}\text { Fallows } \\
(15-30 \\
\text { years }) \\
\text { Bekas ladang }\end{array}$ & 6 & 15 & 16 & 10 & 26 & 11 & 16 \\
\hline $\begin{array}{l}\text { Rubber } \\
\text { garden } \\
\text { Kebun karet }\end{array}$ & 0 & 10 & 8 & 0 & 0 & 0 & 0 & $\begin{array}{l}\text { Rubber } \\
\text { garden } \\
\text { Kebun karet }\end{array}$ & 18 & 13 & 7 & 8 & 0 & 0 & 0 \\
\hline $\begin{array}{l}\text { River } \\
\text { Sungai }\end{array}$ & 15 & 0 & 5 & 15 & 0 & 0 & 0 & $\begin{array}{l}\text { River } \\
\text { Sungai }\end{array}$ & 18 & 0 & 10 & 8 & 0 & 0 & 0 \\
\hline $\begin{array}{l}\text { Total } \\
\text { use per } \\
\text { category }\end{array}$ & 100 & 100 & 100 & 100 & 100 & 100 & 100 & $\begin{array}{l}\text { Total } \\
\text { use per } \\
\text { category }\end{array}$ & 100 & 100 & 100 & 100 & 100 & 100 & 100 \\
\hline
\end{tabular}


Appendix 5. Data sheet for the PDM: Source of income

\begin{tabular}{|c|c|c|c|c|c|c|}
\hline & \multicolumn{3}{|c|}{ Total PDM } & \multirow[t]{2}{*}{ Important ressources } & \multirow[t]{2}{*}{ Price IDR } & \multirow[t]{2}{*}{ Euro } \\
\hline & Men & Women & Total & & & \\
\hline $\begin{array}{l}\text { Primary swamp } \\
\text { forest } \\
\text { Hutan rimba rawa }\end{array}$ & 18 & 10 & 28 & $\begin{array}{l}\text { - Gaharu/gaharu buaya } \\
\text { (resin) } \\
\text { - Plants for basketry: } \\
\text { hats, baskets, traps etc. } \\
\text { - Wood (e.g. tomau) }\end{array}$ & $\begin{array}{l}\cdot 10,000-60,000 / \mathrm{kg} \\
\cdot 25,000-75,000 / \text { piece } \\
\text {. } 300,000-1,000,000 / \text { tree }\end{array}$ & $\begin{array}{l}\cdot 0.8-5 \\
\cdot 2-6 \\
\cdot 24-80\end{array}$ \\
\hline $\begin{array}{l}\text { Primary hill forest } \\
\text { Hutan rimba } \\
\text { gunung }\end{array}$ & 27 & 12 & 39 & $\begin{array}{l}\text { - Wood (e.g. tekam) } \\
\text { - Plants for basketry }\end{array}$ & $\begin{array}{l}\text { - 300,000-1,000,000/tree } \\
\text {. 25,000-75,000/piece }\end{array}$ & $\begin{array}{l}\cdot 24-80 \\
\cdot 2-6\end{array}$ \\
\hline $\begin{array}{l}\text { Secondary forest } \\
\text { Hutan babas }\end{array}$ & 0 & 9 & 9 & - Wood (e.g. meranti) & - 300,000-1,000,000/tree & - $24-80$ \\
\hline $\begin{array}{l}\text { Protected forest } \\
\text { Hutan lindungi }\end{array}$ & 0 & 0 & 0 & - & - & - \\
\hline $\begin{array}{l}\text { Swidden } \\
\text { Ladang }\end{array}$ & 11 & 15 & 26 & - Rice and vegetables & - $5,000-12,000 / \mathrm{kg}$ & - $0,4-1$ \\
\hline $\begin{array}{l}\text { Fallows (1-5 } \\
\text { years) } \\
\text { Bekas ladang }\end{array}$ & 0 & 8 & 8 & - Vegetables & - $5,000 / \mathrm{kg}-12,000 / \mathrm{kg}$ & - $0.4-1$ \\
\hline $\begin{array}{l}\text { Fallows (5-15 } \\
\text { years) } \\
\text { Bekas ladang }\end{array}$ & 8 & 12 & 20 & $\begin{array}{l}\text { - Firewood } \\
\text { - Plants for basketry }\end{array}$ & $\begin{array}{l}\text { - 5,000/basket } \\
\text {. 25,000-75,000/piece }\end{array}$ & $\cdot 0.4$ \\
\hline $\begin{array}{l}\text { Fallows (15-30 } \\
\text { years) } \\
\text { Bekas ladang }\end{array}$ & 15 & 8 & 23 & $\begin{array}{l}\text { - Wood (e.g. belantik) } \\
\text { - Plants for basketry }\end{array}$ & $\begin{array}{l}\text { - 300,000-1,000,000/tree } \\
\text {. 25,000-75,000/piece }\end{array}$ & $\begin{array}{l}\cdot 24-80 \\
\cdot 2-6\end{array}$ \\
\hline $\begin{array}{l}\text { Rubber garden } \\
\text { Kebun karet }\end{array}$ & 6 & 17 & 23 & - Rubber & - $5,000-10,000 / \mathrm{kg}$ & - $0.4-0,8$ \\
\hline $\begin{array}{l}\text { River } \\
\text { Sungai }\end{array}$ & 15 & 9 & 24 & $\begin{array}{l}\text { - } \text { Fish } \\
\text { - Sandstone } \\
\text { - Gold }\end{array}$ & $\begin{array}{l}\text { - } 30,000 / \mathrm{kg} \\
\text { - } 8,000 / \mathrm{m}^{3} \\
\text { - } 500,000 / \mathrm{g}\end{array}$ & $\begin{array}{ll}\cdot & 2.4 \\
\cdot & 0.7 \\
\cdot & 42.6\end{array}$ \\
\hline
\end{tabular}


Appendix 6. Data Sheet for the PDM: Past present future

\section{MEN}

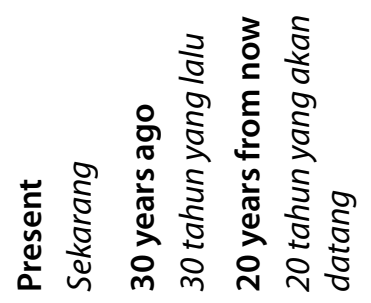

Primary swamp forest

Hutan rimba rawa

$\begin{array}{llll}\text { Primary hill forest } & 23 & 27 & 5\end{array}$

Hutan rimba gunung

\begin{tabular}{lccc}
\hline $\begin{array}{l}\text { Secondary forest } \\
\text { Hutan babas }\end{array}$ & 3 & 4 & 20 \\
\hline $\begin{array}{l}\text { Protected forest } \\
\text { Hutan adat }\end{array}$ & 2 & 0 & 12 \\
\hline $\begin{array}{l}\text { Swidden } \\
\text { Ladang }\end{array}$ & 21 & 21 & 7 \\
\hline $\begin{array}{l}\text { Fallows (1-5 years) } \\
\text { Bekas ladang }\end{array}$ & 2 & 2 & 2 \\
\hline $\begin{array}{l}\text { Fallows (5-15 years) } \\
\text { Bekas ladang }\end{array}$ & 2 & 2 & 5 \\
\hline $\begin{array}{l}\text { Fallows (15-30 years) } \\
\text { Bekas ladang }\end{array}$ & 4 & 10 & 12 \\
\hline $\begin{array}{l}\text { Rubber garden } \\
\text { Kebun karet }\end{array}$ & 23 & 5 & 12 \\
\hline $\begin{array}{l}\text { River } \\
\text { Sungai }\end{array}$ & 18 & 21 & 21 \\
\hline \begin{tabular}{l} 
Total use per category \\
\hline
\end{tabular} & 100 & 100 & 100 \\
\hline
\end{tabular}

\section{WOMEN}

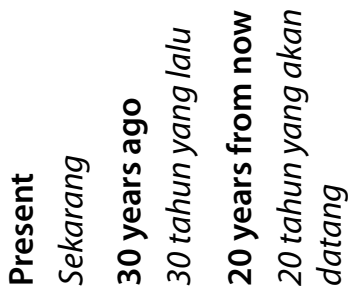

\begin{tabular}{llll}
\hline Primary swamp forest & 13 & 11 & 10
\end{tabular}

Hutan rimba rawa

$\begin{array}{llll}\text { Primary hill forest } & 13 & 11 & 9\end{array}$

Hutan rimba gunung

\begin{tabular}{llll}
\hline $\begin{array}{l}\text { Secondary forest } \\
\text { Hutan babas }\end{array}$ & 4 & 7 & 2 \\
\hline Protected forest & 2 & 6 & 9
\end{tabular}

Hutan adat

$\begin{array}{llll}\text { Swidden } & 12 & 17 & 16\end{array}$

Ladang

Fallows (1-5 years) $\quad 5 \quad 10 \quad 10$

Bekas ladang

Fallows (5-15 years) $\quad 5 \quad 5 \quad 5$

Bekas ladang

\begin{tabular}{lccc}
$\begin{array}{l}\text { Fallows (15-30 years) } \\
\text { Bekas ladang }\end{array}$ & 5 & 11 & 5 \\
\hline $\begin{array}{l}\text { Rubber garden } \\
\text { Kebun karet }\end{array}$ & 28 & 11 & 21 \\
\hline $\begin{array}{l}\text { River } \\
\text { Sungai }\end{array}$ & 13 & 11 & 13 \\
\hline \begin{tabular}{l} 
Total use per category \\
\hline
\end{tabular} & 100 & 100 & 100 \\
\hline
\end{tabular}




\section{Appendix 7. The nine remedies other then plants}

\begin{tabular}{|c|c|c|c|}
\hline Local name & Use & What part & Procedure \\
\hline Kulat mangkut (Auricularia sp.) & Urinary pain & Mushroom & Eat \\
\hline Kulat badung & Fever, malaria & Mushroom & Cook and rub against belly \\
\hline Kulat pahunan & Chase Satan & Mushroom & Eat, drink tea or use smoke \\
\hline Kujung tuntung & Chase Satan & Snail shell & Eat mixed with meat \\
\hline Kapur & Toothache & Riversnail shell & Chew and spit out \\
\hline Burung hiram & Nose bleeding & Birdsnest & Cook and make compress \\
\hline Kancil (Tragulus javanicus) & Childgiving & Embryo & Eat \\
\hline Senengir (Cicadoidea sp.) & Baby cries at late afternoon & Exoskeleton of cicada & Burn and let baby breath smoke \\
\hline Burung tajak (Bucerotidae sp.) & Headache & Skull of bird, blackened in fire & $\begin{array}{l}\text { Rub with knife particles from the skull, mix with water and } \\
\text { put on head }\end{array}$ \\
\hline
\end{tabular}


Appendix 8. List of the 125 medicinal plants, with their local name, scientific name, use, part used, route of administration, location and planting ( $\mathrm{N}=$ not planted, $\mathrm{Y}=$ planted)

\begin{tabular}{|c|c|c|c|c|c|c|c|c|c|}
\hline Local name & Family & Genus & Species & Author & Use & Plant part & Procedure & Location & Planted \\
\hline Akar batuk ontis & Vitaceae & Vitis & $\mathrm{sp}$. & & Cough & Leave & Attach compress on throat & $\begin{array}{l}\text { Primary forest/ } \\
\text { fallows }\end{array}$ & $\mathrm{N}$ \\
\hline Akar kepati & Rubiaceae & Hemidiodea & atimifolia* & Shum. & Abdominal pain & Leave & Compress on belly or drink tea & Village & $\mathrm{N}$ \\
\hline Akar kuning & Menispermaceae & Fibraurea & tinctoria & Lour. & Malaria, jaundice, rheumatic pains & Root & Boil in water and wash body & Primary forest & $\mathrm{N}$ \\
\hline Akar leburlaling & Vitaceae & Vitis & papillosa & Backer & Fever & Root & $\begin{array}{l}\text { Boil in water and wash body or } \\
\text { mash and put on forehead }\end{array}$ & Garden & $\mathrm{Y}$ \\
\hline Akar pujut & Orchidaceae & Agrostophyllum & sp. & & Jaundice, fever & Leave & Boil in water and wash body & Primary forest & $\mathrm{N}$ \\
\hline Akarpunan & Vitaceae & Ampelocissus & thyrsiflora & Planch & Wound & Root & Compress on wound & $\begin{array}{l}\text { Primary forest/ } \\
\text { fallows }\end{array}$ & N \\
\hline Akar rejan & Lamiaceae & Leucas & lavandulifolia & Sm. & Defecate blood & Root & Drink tea or eat & $\begin{array}{l}\text { Village/ } \\
\text { garden/ } \\
\text { fallows }\end{array}$ & $\mathrm{N}$ \\
\hline Anti & Apocynaceae & Hoya & diversifolia* & $B l$. & $\begin{array}{l}\text { Fever, jaundice, stomach ache } \\
\text { (bloating) }\end{array}$ & Whole plant & Compress on temples & Primary forest & N \\
\hline Api & Rubiaceae & Coptophyllum & fulvum & Bakh.f. & Drop body heat & Leave & Compress & River & $\mathrm{N}$ \\
\hline Badi kalui + & Amaranthaceae & Amaranthus & sp. & & Nausea, stiffness, stomach ache & Root and leave & Boil in water and wash body & River & $\mathrm{N}$ \\
\hline Banar & Smilacaceae & Smilax & zeylanica & $L$. & Mouth and throat infected & Root & Rinse mouth with tea & Fallows & $\mathrm{N}$ \\
\hline "Baru bangung" & Iridaceae & Eleutherine & bulbosa & Urb. & Revive dead & Leave & Compress on forehead & Village & $\mathrm{Y}$ \\
\hline Bawang moka & Compositae & Ageratum & conyzoides & $L$. & Urinating blood & Leave & Drink tea & Village & Y \\
\hline Belaban & Myrtaceae & Tristaniopsis & merguensis & Ridl. & Fever & Leave & Drink tea & Primary forest & $\mathrm{N}$ \\
\hline Belaban merah & Myrtaceae & Tristaniopsis & sp. & & Stomach ache & Red bark & Drink tea & Primary forest & $\mathrm{N}$ \\
\hline Bengkal air & Myrtaceae & Syzygium & sp. & & Itchy skin & Leave & Boil in water and wash body & River & $\mathrm{N}$ \\
\hline Bunga dewa & Compositae & Gynura & japonica & Juel & Lowering high blood pressure & Dried fruit & Drink tea & Village & Y \\
\hline Bunga kambak & Malvaceae & Hibiscus & rosa-sinensis & Linn. & Fever & Leave & Compress & Garden & $\mathrm{Y}$ \\
\hline Bungur & Polypodiaceae & Platycerium & bifurcatum & C.Chr. & Stomach ache & Leave & Drink tea & Village & $\mathrm{N}$ \\
\hline Cikor & Zingiberaceae & Kaempferia & galanga & $L$. & Fever in children & Whole plant & Put compress on head & Village & $\mathrm{Y}$ \\
\hline Daun belaian & Convolvulaceae & Operculina & turpethum & Manso. & Malaria, stomach ache in children & Leave & $\begin{array}{l}\text { Moisten with hot water and put } \\
\text { on head or drink tea }\end{array}$ & Garden & $\mathrm{N}$ \\
\hline Dugan & Dryopteridaceae & Tectaria & zeylanica & Sledge & Wound inside the body & Fruit and leave & Eat and drink tea & Village & $\mathrm{N}$ \\
\hline Enkabut & Phyllanthaceae & Breynia & racemosa & Muell.Arg. & Itching wound & Leave & Mash and put on wound & Fallows & $\mathrm{N}$ \\
\hline Enklaiu & Apiaceae & Trachyspermum & ammi & (L.) Sprague & Jaundice & Whole plant & Cook and eat & Primary forest & $\mathrm{N}$ \\
\hline Entatung & Meliaceae & Azadirachta & indica & Juss & Strabismus & Root tuber & Chew and spit on head of patient & Village/fallows & Y \\
\hline
\end{tabular}


Appendix 8. continued

\begin{tabular}{|c|c|c|c|c|c|c|c|c|c|}
\hline Local name & Family & Genus & Species & Author & Use & Plant part & Procedure & Location & Planted \\
\hline Entepung buluk & Euphorbiaceae & Mallotus & paniculatus & Muell.Arg. & Stiffness from fever, shivering & Leave & Compress & Fallows & $\mathrm{N}$ \\
\hline Entima & Rubiaceae & Ophiorrhiza & sanguinea & $B I$. & Wound, fever & Leave & Mash or boil & Fallows & $\mathrm{N}$ \\
\hline Ginseng $q$ & Icacinaceae & Stemonorus & scorpioides* & Becc. & Kidney disease, malaria & Root & Drink tea & Primary forest & $\mathrm{N}$ \\
\hline Ginseng $\widehat{\jmath}$ & Icacinaceae & Stemonorus & secundiflora* & Bl. & Kidney disease, malaria & Root & Drink tea & Primary forest & $\mathrm{N}$ \\
\hline Ilung asam & Araceae & Schismatoglottis & rupestris & Zoll. & Chase satan & Root tuber & Boil in water and wash body & Primary forest & $\mathrm{N}$ \\
\hline Ilung pagung & Flagellariaceae & Flagellaria & indica & $L$. & Body pain & Root & Drink tea & Primary forest & $\mathrm{N}$ \\
\hline Itap labi-labi & Gentianaceae & Fagraea & racemosa & Jack. & Fever & Leave & Boil in water and wash body & Fallows & $\mathrm{N}$ \\
\hline $\begin{array}{l}\text { Jambu air } \\
\text { (=Serugan) }\end{array}$ & Leguminosae & Senna & alata & (L.) Roxb. & Itchy skin & Leave & Boil in water and wash body & River & $\mathrm{N}$ \\
\hline Jari & Compositae & Sonchus & arvensis & L. & Childbirth & Leave & Drink tea & River & $\mathrm{N}$ \\
\hline Jerangan & Acoraceae & Acorus & calamus & $L$. & Stomach ache, nausea (in babies) & Root tuber & Eat or compress & Garden & Y \\
\hline Jonong akar & Rhamnaceae & Zizyphus & jujuba & Lamk. & Insect, snake and centipede bites & White sap & Put on bite & Garden/Village & $Y$ \\
\hline Juaran bolang & Rubiaceae & Ophiorrhiza & sp. & & Body pain from fever & Leave & Mash and put on body & Garden & $\mathrm{Y}$ \\
\hline Juaran kuning & Euphorbiaceae & Codiaeum & sp. & & Fever, drop body heat & Leave & Boil in water and wash body & Garden & $\mathrm{Y}$ \\
\hline Juaran merah & Euphorbiaceae & Codiaeum & variegatum & Juss & Body pain and stiffness, fever & Leave & Compress & Garden & $\mathrm{N}$ \\
\hline Juaran padi & Euphorbiaceae & Codiaeum & sp. & & Fever, drop body heat & Leave & Boil in water and wash body & Garden & $\mathrm{Y}$ \\
\hline Juaran tua & Apocynaceae & Strophanthus & sp. & & Body pain & Leave & Compress & Garden & $\mathrm{Y}$ \\
\hline Kankung & Compositae & Austroeupatorium & inulifolium & Rob. & Sleeplessness & Leave & Eat a lot & River & $\mathrm{N}$ \\
\hline $\begin{array}{l}\text { Kayu nadjam } \\
\text { (=Kunidin) }\end{array}$ & Blechnaceae & Stenochlaena & palustris & Bedd. & Body pain & Leave & Cook and rub on body & Fallows & $\mathrm{N}$ \\
\hline Kayu pata issau & Myrtaceae & Eucalyptus & deglupta & BI. & $?$ & Leave & $?$ & Primary forest & $\mathrm{N}$ \\
\hline Kayu suak & Sapindaceae & Otophora & spectabilis & $B l$. & Fever & Leave & Boil in water and wash body & $\begin{array}{l}\text { Primary forest/ } \\
\text { fallows }\end{array}$ & $\mathrm{N}$ \\
\hline Kekarut & Elaeocarpaceae & Sloanea & javanica & Ridl. & Chase satan off the house & Fruit & Burn and use smoke & Primary forest & $\mathrm{N}$ \\
\hline Kemuntin & Melastomataceae & Melastoma & malabathricum & $L$. & $\begin{array}{l}\text { Desinfect a bleeding wound, } \\
\text { cholesterol, },+ \text { menstruation }\end{array}$ & Leave & $\begin{array}{l}\text { Mash with hot water and put on } \\
\text { wound, drink tea }\end{array}$ & Garden & $\mathrm{N}$ \\
\hline Kenjin jawa & Leguminosae & Archidendron & clypearia & Nielsen & Nausea, stomach ache & Fruit & Compress or drink tea & Primary forest & $\mathrm{N}$ \\
\hline Kibang & Compositae & Acmella & $a l b a$ & Jansen & Swollen legs & Root & Cook and make compress & Village & $\mathrm{Y}$ \\
\hline Kubung & Euphorbiaceae & Macaranga & gigantea & Muell.Arg. & Gingivitis in little children & Resin & Put resin on teethridge & Garden & $\mathrm{N}$ \\
\hline Kumis kucing & Lamiaceae & Orthosiphon & aristatus & (Blume) Miq & Abdominal and low back pain & Leave & Drink tea & Garden & $\mathrm{Y}$ \\
\hline
\end{tabular}


Appendix 8. continued

\begin{tabular}{|c|c|c|c|c|c|c|c|c|c|}
\hline Local name & Family & Genus & Species & Author & Use & Plant part & Procedure & Location & Planted \\
\hline $\begin{array}{l}\text { Kunidin }(=\text { Kayu } \\
\text { nadjam })\end{array}$ & Blechnaceae & Stenochlaena & palustris & Bedd. & Blood disease & Leave & Drink tea & Fallows & $\mathrm{N}$ \\
\hline Kunyit hitam & Zingiberaceae & Curcuma & sp. & & Rheumatic pains & Root tuber & Drink tea & Village & $\mathrm{Y}$ \\
\hline Kunyit merah & Zingiberaceae & Curcuma & aeruginosa & Roxb. & Fever & Leave & Eat or compress & Garden & Y \\
\hline Kunyit putih & Zingiberaceae & Curcuma & sp. & & Stomach ache, heartburn & Root tuber & Drink tea & Garden/Village & Y \\
\hline Lada & Lauraceae & Cinnamomum & sp. & & $\begin{array}{l}\text { Chase satan in children and birth } \\
\text { giving }\end{array}$ & Wood & Burn and use smoke & Primary forest & $\mathrm{N}$ \\
\hline Lahiak & Poaceae & Panicum & sp. & & $\begin{array}{l}\text { P just finished childbirth, rheumatic } \\
\text { pain }\end{array}$ & Leave & Mash and put on limbs & Garden & Y \\
\hline Laluma sungai & Lamiaceae & Scutellaria & discolor & Colebr. & Abdominal pain, body pain & Root & Make tea or compress & Village & $\mathrm{N}$ \\
\hline Leban & Lamiaceae & Vitex & pinnata & $L$. & Stomach ache & Leave & Compress on belly & Garden & $\mathrm{N}$ \\
\hline Lengan & Rubiaceae & Neonauclea & calycina & Merr. & Stomach ache & Leave & Compress & Village/fallows & $\mathrm{N}$ \\
\hline Lengat & Rubiaceae & Dentella & repens & Forst. & Stomach ache & Whole plant & Mash and put on belly & Village & $\mathrm{N}$ \\
\hline Lensurai & Dipterocarpaceae & Dipterocarpus & sp. & & Stomach ache, fever & Bud & Drink tea & Primary forest & $\mathrm{N}$ \\
\hline Lukai & Annonaceae & Goniothalamus & sp. & & Chase satan out of little children & Leave & Cook and eat & Primary forest & $\mathrm{N}$ \\
\hline Mali-mali & Rubiaceae & Oldenlandia & verticillata & L. & Ulcer & Leave & Mash and put on ulcer & Fallows & $\mathrm{N}$ \\
\hline $\begin{array}{l}\text { Mambung } \\
\text { (=R.pelekambing) }\end{array}$ & Compositae & Blumea & lacera & $D C$ & $\begin{array}{l}\text { Headache, stomach ache, childbirth, } \\
\text { hot body }\end{array}$ & Leave & $\begin{array}{l}\text { Moisten and put on head or } \\
\text { stomache }\end{array}$ & Garden & $\mathrm{N}$ \\
\hline Mata ikan & Lamiaceae & Callicarpa & candicans & L. & Fever, nausea, wound & Leave & Drink tea or compress on wound & Primary forest & $\mathrm{N}$ \\
\hline Mayagana & Polypodiaceae & Platycerium & bifurcatum & C.Chr. & Ear infection & Root and leave & $\begin{array}{l}\text { Put compress with root on ear, } \\
\text { mash leave with water pour in } \\
\text { ear }\end{array}$ & Primary forest & $\mathrm{N}$ \\
\hline Melimbing tujuk & Oxalidaceae & Averrhoa & bilimbi & L. & Blood disease & Fruit/dried leave & Eat fruit or drink tea with leave & Village & Y \\
\hline Mengkudo & Rubiaceae & Morinda & citrifolia & $L$. & High blood pressure & Leave and fruit & Drink tea or eat & Village & Y \\
\hline Mentemu & Zingiberaceae & Curcuma & longa & L. & Typhus, malaria & Fruit & Drink tea & Village & $Y$ \\
\hline Merumbun & Crassulaceae & Bryophyllum & pinnatum & Oken & Fever/Patient can't have children & Leave & $\begin{array}{l}\text { Make cuts in leave and put on } \\
\text { forehead/Mash with egg and } \\
\text { water and drink before dinner }\end{array}$ & Village & Y \\
\hline Mudan & Dilleniaceae & Dillenia & eximia & Miq. & Childbirth & Leave & Boil in water and wash body & Village & $\mathrm{N}$ \\
\hline Muntan & Lycopodiaceae & Lycopodium & cernuum & Linn. & Wound & Leave & Mash and put on wound & Fallows & $\mathrm{N}$ \\
\hline Ningon & Acanthaceae & Strobilanthes & crispa* & Bl. & Cough/stomach ache & Whole plant & $\begin{array}{l}\text { Boil in water and wash body/ } \\
\text { cook and put on belly }\end{array}$ & Village & $\mathrm{N}$ \\
\hline Pahang raugn & Piperaceae & Piper & attenuatum & Miq. & Childbirth & Leave & Heat over fire and put on belly & Village/fallows & Y \\
\hline
\end{tabular}


Appendix 8. continued

\begin{tabular}{|c|c|c|c|c|c|c|c|c|c|}
\hline Local name & Family & Genus & Species & Author & Use & Plant part & Procedure & Location & Planted \\
\hline Pakukele & Compositae & Elephantopus & scaber & $L$. & Nausea, fever, urinary pain & Root, leave & $\begin{array}{l}\text { Make tea or compress with root, } \\
\text { eat leave }\end{array}$ & Village & $\mathrm{N}$ \\
\hline Pakumani & Leguminosae & Crotalaria & incana & $L$. & Lower back pain (lumbago), headache & Fruit & Rub fruit on forehead & Village & $\mathrm{N}$ \\
\hline Palang burung & Apiaceae & Eryngium & foetidum & $L$. & Malaria & Leave & Mash and eat or drink tea & Garden & Y \\
\hline Palau lombat & Orchidaceae & Dendrobium & sp. & & Itchy skin & Leave & Boil in water and wash skin & Village & $\mathrm{N}$ \\
\hline Pamo bensi & Marantaceae & Phrynium & pubinerve & Bl. & Defecate blood & Whole plant & Drink tea & Primary forest & $\mathrm{N}$ \\
\hline Pamunkar & $?$ & & & & Tumor, nausea, urinary pain & Fruit & Cook and rub on body & Primary forest & $\mathrm{N}$ \\
\hline Pandang uangi & Pandanacea & Pandanus & amaryllifolius & Roxb. & Kidney stone & Leave & Drink tea & Village & Y \\
\hline Pang pahit & Cyperaceae & Cyperus & difformis & $L$. & Urinary pain & Leave & Drink tea & Village & $\mathrm{N}$ \\
\hline Panjurong isi & Phyllanthaceae & Phyllanthus & niruri & $L$. & Wound & Whole plant & Mash and put on wound & Village & $\mathrm{N}$ \\
\hline Parap ampar & Rubiaceae & Argostemma & montamun & Bl. & Tooth ache & Whole plant & Drink tea & Village & $\mathrm{N}$ \\
\hline Parap ensilip ${ }^{\top}$ & Cyperaceae & Fimbristylis & acuminata & Vahl. & Nausea, stomach ache & Whole plant & Put compress on throat, drink tea & Village & $\mathrm{N}$ \\
\hline Parap matu & Lamiaceae & Hyptis & capitata & Jacq. & $?$ & Leave & $?$ & Primary forest & $\mathrm{N}$ \\
\hline Parap rasa & Compositae & Cyanthillium & cinereum & Rob. & Stomach ache & Whole plant & Cook and put on belly & Village & $\mathrm{N}$ \\
\hline Parapapi & Plantaginaceae & Plantago & major & $L$. & Cold body, fever & Leave & Compress & River & $\mathrm{N}$ \\
\hline Pasak bumi & Simaroubaceae & Eurycoma & longifolia & Jack. & Backhurt, fever, malaria & Root & Drink tea & Primary forest & $\mathrm{N}$ \\
\hline Pasap mata hari & Compositae & Ageratum & conyzoides & $L$. & Headache & Leave & Put compress on forehead & $\begin{array}{l}\text { Garden/ } \\
\text { fallows }\end{array}$ & N \\
\hline Pengensit & Leguminosae & Senna & siamena & Lamk. & Sore eyes & Leave, bark, fruit & Boil in water and wash eyes & $\begin{array}{l}\text { Garden/ } \\
\text { Primary forest }\end{array}$ & N \\
\hline Petampal & Compositae & Mikania & scandens & Willd. & Fever & Leave & Boil in water and wash body & Village & $Y$ \\
\hline Piawas & Lauraceae & Litsea & brachystachya* & Boerl. & Cough, sore throat & Leave & Mash and spit out & $\begin{array}{l}\text { Primary forest/ } \\
\text { fallows }\end{array}$ & N \\
\hline Pingsan tabun & Phyllanthaceae & Phyllanthus & pulcher & Wall. & Fainting & Leave & Compress on body & Fallows & $\mathrm{N}$ \\
\hline Pringat & Rosaceae & Rubus & moluccanus* & Kuntze & Sore throat, cold/ tooth ache & Leave and stem & $\begin{array}{l}\text { Drink tea/ chew leave on sick } \\
\text { tooth }\end{array}$ & Garden & N \\
\hline Purung haras & Leguminosae & Arbus & precatorius & $L$. & Baby cries & Fruit and leave & Mash and put on head & Village/fallows & Y \\
\hline Rabun ayam & Compositae & Synedrella & nodiflora & Gaernt. & Eyes do not see well & Leave & Boil in water and wash eyes & Village/fallows & $\mathrm{N}$ \\
\hline Ransak balun & Aspleniaceae & Asplenium & nidus & $L$. & Tumor, nausea, urinary pain & Leave & Cook and make compress & Primary forest & $\mathrm{N}$ \\
\hline Rumput batu & Rubiaceae & Oldenlandia & recurva & Miq. & Fever & Root & Cook and make compress & Primary forest & $\mathrm{N}$ \\
\hline Rumput langau & Apiaceae & Centella & asiatica & (L.)Urb. & Help the newborn to breath & Leave & Compress on head & Garden/Village & $\mathrm{N}$ \\
\hline
\end{tabular}


Appendix 8. continued

\begin{tabular}{|c|c|c|c|c|c|c|c|c|c|}
\hline Local name & Family & Genus & Species & Author & Use & Plant part & Procedure & Location & Planted \\
\hline $\begin{array}{l}\text { Rumput } \\
\text { pelekambing } \\
\text { (=Mambung) }\end{array}$ & Compositae & Blumea & lacera & $D C$ & Stomach ache & Leave & Compress & Garden/Village & $\mathrm{Y}$ \\
\hline $\begin{array}{l}\text { Sabang hijao } \\
\text { (=Sabang merah) }\end{array}$ & Asparagaceae & Cordyline & fruticosa & Chev. & Fever & Leave & Compress & Village & $\mathrm{Y}$ \\
\hline $\begin{array}{l}\text { Sabang merah } \\
\text { (=Sabang hijao) }\end{array}$ & Asparagaceae & Cordyline & fruticosa & Chev. & $\begin{array}{l}\text { Fever, chase satan, headache, blood } \\
\text { diseases }\end{array}$ & Leave & Mash and eat or drink tea & Garden & $\mathrm{Y}$ \\
\hline Sandang & Rubiaceae & Psychotria & sp. & & Pain in the ribs area, fever & $\begin{array}{l}\text { Only white } \\
\text { leaves }\end{array}$ & Cook and rub on body & Garden & $\mathrm{N}$ \\
\hline Sanduk & Lauraceae & Cinnamomum & kerangas & Kosterm. & Chase satan, fever & Bark & Burn and use smoke & $\begin{array}{l}\text { Primary forest/ } \\
\text { fallows }\end{array}$ & $\mathrm{N}$ \\
\hline Sarang kemutah & Acanthaceae & Graptophyllum & pictum & (L)Griff & Nausea & Whole plant & Eat or drink tea & River & $\mathrm{N}$ \\
\hline Sarang semut & Picrodendraceae & Austrobuxus & nitidus & Miq. & High blood pressure, cancer, stroke & Dried tuber & Drink tea & Primary forest & $\mathrm{N}$ \\
\hline Segah & Rubiaceae & Streblosa & tortilis & Korth. & Dizziness, nausea & Leave and root & Cook and make compress & Primary forest & $\mathrm{N}$ \\
\hline Selasi & Passifloraceae & Passiflora & foetida & $L$. & Fever, jaundice & Leave and root & Eat, drink tea or wash body & Garden & $\mathrm{N}$ \\
\hline Seraibangi & Graminae & Andropogon & nardus & Linn. & Fever & Whole plant & Boil in water and wash body & Village & $\mathrm{Y}$ \\
\hline $\begin{array}{l}\text { Serugan (=Jambu } \\
\text { air) }\end{array}$ & Leguminosae & Senna & alata & (L.) Roxb. & Itchy skin, running nose & Dried leave & Smoke the leave & Village & $\mathrm{N}$ \\
\hline Siloh & Orchidaceae & Habenaria & sp. & & Sore and red eyes, nausea & Whole plant & Compress on eyes, drink tea & Primary forest & $\mathrm{N}$ \\
\hline Siluh helang & Leguminosae & Inocarpus & fagifer & Fosberg & Sore throat/Pain in the legs & Leave & Drink tea/Mash and put on legs & Garden & $\mathrm{N}$ \\
\hline Sudah kuku & Orchidaceae & Dendrobium & sp. & & Ulcer, swollen skin & Whole plant & Cook and make compress & Primary forest & $\mathrm{N}$ \\
\hline Surugan & Vitaceae & Leea & angulata & Merr. & Allergic reaction (also in cats and dogs) & Leave & Mash, wash skin with it (+soap) & Village & $\mathrm{Y}$ \\
\hline Tabar & Costaceae & Tapeinochilos & ananassae & K.Sch & Sudden sickness, fever & Leave & Boil in water and wash body & Garden & $\mathrm{N}$ \\
\hline Tarum buaya & Rubiaceae & Oldenlandia & biflora & L. & Stomach ache & Leave & $\begin{array}{l}\text { Put on belly with leaves pointing } \\
\text { to the back }\end{array}$ & Fallows & $\mathrm{N}$ \\
\hline $\begin{array}{l}\text { Tebu buah (=Tebu } \\
\text { merah) }\end{array}$ & Poaceae & Saccarum & officinarum & $L$. & Body pain & Sap & Eat & Village & $\mathrm{Y}$ \\
\hline Tebu Ialin & Convolvulaceae & Ipomoea & aquatica & Forssk. & Fever & Leave & Boil in water and wash body & Garden & $\mathrm{Y}$ \\
\hline $\begin{array}{l}\text { Tebu merah } \\
(=\text { Tebu buah) }\end{array}$ & Poaceae & Saccarum & officinarum & $L$. & Defecate/urinate blood & Sap & Eat & Village & $\mathrm{Y}$ \\
\hline Tempilak merah & Leguminosae & Bauhinia & acuminata & $L$. & Fever in children & Whole plant & Drink tea & Village/fallows & Y \\
\hline Tenkorokang & Leguminosae & Abrus & precatorius & $L$. & Throat infection & Root & Eat & Village & $\mathrm{Y}$ \\
\hline Ubai & Myrtaceae & Syzygium & sp. & & Childbirth & Leave & Eat (with meat) & Fallows & $\mathrm{N}$ \\
\hline "Xpussing" & Selaginellaceae & Selaginella & uncinata & Spring & Headache, dizziness, nausea & Whole plant & Compress on head & Primary forest & $\mathrm{N}$ \\
\hline
\end{tabular}

* it has not yet been determined whether the name is a synonym or has been accepted, according to The Plant List (2010) 

CIFOR Working Papers contain preliminary or advance research results on tropical forest issues that need to be published in a timely manner to inform and promote discussion. This content has been internally reviewed but has not undergone external peer review.

This study aims to introduce the natural resource uses of Dayak Mentebah people of the village Nanga Dua, West Kalimantan. It is part of the project CoLUPSIA that focuses on reinforcing small stakeholder's rights. Furthermore, ecological data are collected to support the protection of Indonesia's species rich and vulnerable tropical forests, threatened through high deforestation rates. The local people's perceptions about their environment and land uses were assessed using participatory survey techniques: focus group discussions, scoring exercises, free lists of species and participatory mapping. To further record the traditional practices a survey was conducted on medicinal plants. The ecological assessment was done through survey plots in different land use units, where tree diversity and diameter at breast height was measured. The inhabitants of Nanga Dua are dependent upon forest products for food, material for construction, basketry, etc. Medicinal plants are integral part of the health-care system. The traditional, shifting cultivation creates a diverse and mosaic-like patchwork of various types of forests, having different successional stages. Tree diversity in the land-use units was generally high, with the primary forest in immediate proximity acting as tree species reservoir.

This research was carried out as part of the European Union funded Collaborative Land Use Planning and Sustainable Institutional Arrangement project (CoLUPSIA). Run by CIRAD in partnership with CIFOR, TELAPAK and several local NGOs and Universities, the project aims to contribute to avoided environmental degradation and to strengthen land tenure and community right by collaboratively integrating all stakeholders' views in land-use planning processes. The outputs revolve around the relationship between land use planning, land allocation and the provision and potential payment of ecosystem services. The project focuses on two regencies (kabupaten), Kapuas Hulu and Central Maluku in Indonesia.
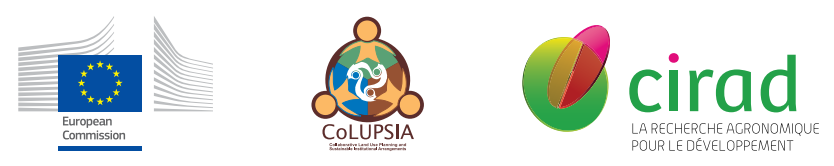